\title{
TP53-mediated clonal hematopoiesis confers increased risk for incident peripheral artery disease
}

Seyedeh M. Zekavat BS ${ }^{1-4 *}$, Vanesa Viana-Huete $\mathrm{PhD}^{5 *}$, María A. Zuriaga $\mathrm{PhD}^{5}$, Md Mesbah Uddin $\mathrm{PhD}^{3,4}$, Mark Trinder $\mathrm{BS}^{3,4,6}$, Kaavya Paruchuri $\mathrm{MD}^{3,4,7}$, Nuria Matesanz $\mathrm{PhD}^{5}$, Virginia Zorita BS MSc ${ }^{5}$, Alba Ferrer-Pérez BS MSc ${ }^{5}$, Marta Amorós-Pérez BS $\mathrm{MSc}^{5}$, Scott M.

Damrauer $\mathrm{MD}^{8}$, Christie M. Ballantyne MD ${ }^{9}$, Abhishek Niroula PhD ${ }^{3,10}$, Christopher J. Gibson $\mathrm{MD}^{10}$, James Pirruccello MD ${ }^{3}$, Gabriel Griffin $\mathrm{MD}^{11}$, Benjamin L. Ebert MD $\mathrm{PhD}^{12}$, Peter Libby $\mathrm{MD} \mathrm{PhD}^{7}$, Valentín Fuster MD PhD ${ }^{5,13}$, Hongyu Zhao $\mathrm{PhD}^{14}$, Pradeep Natarajan MD $\mathrm{MMSc}^{3,4,7 \S}$, Alexander G. Bick MD PhD ${ }^{3,158}$, José J Fuster PhD ${ }^{5,16 \S}$, Derek Klarin MD

1. Yale School of Medicine, New Haven, CT;

2. Computational Biology \& Bioinformatics Program, Yale University, New Haven, CT, USA;

3. Program in Medical and Population Genetics, Broad Institute of MIT and Harvard, Cambridge, MA, USA;

4. Cardiovascular Research Center, Massachusetts General Hospital, Boston, MA, USA;

5. Centro Nacional de Investigaciones Cardiovasculares (CNIC), Madrid, Spain;

6. Center for Heart Lung Innovation, University of British Columbia, Vancouver;

7. Department of Medicine, Harvard Medical School, Boston, MA, USA;

8. Department of Surgery, Perelman School of Medicine, University of Pennsylvania, Philadelphia, PA, USA;

9. Center for Cardiometabolic Disease Prevention, Baylor College of Medicine, Houston, TX, USA;

10. Department of Medical Oncology, Dana-Farber Cancer Institute, Boston, MA, USA;

11. Department of Pathology, Brigham and Women's Hospital, Boston, MA, USA;

12. Department of Hematology, Brigham and Women's Hospital, Boston, MA, USA;

13. Icahn School of Medicine at Mount Sinai, New York, NY, USA;

14. Department of Biostatistics, Yale School of Public Health, New Haven, CT;

15. Division of Genetic Medicine, Department of Medicine, Vanderbilt University Medical Center, TN, USA;

16. CIBER en Enfermedades Cardiovasculares (CIBER-CV), Madrid, Spain;

17. Malcolm Randall VA Medical Center, Gainesville, FL;

18. Division of Vascular Surgery, University of Florida College of Medicine, FL, USA

* Co-first authors

$\S$ Equally supervised this work

Corresponding Authors:

Jose J. Fuster, PhD

jjfuster@cnic.es

Melchor Fernández Almagro, 3

28029 - Madrid (Spain)

Tel: (+34) 914531200, ext 4304

Fax: (+34) 914531265

Twitter: @josejfuster

ORCID: 0000-0002-5970-629X

Derek Klarin, MD

derek.klarin@surgery.ufl.edu

1600 SW Archer Road, NG-45, PO Box 100128, Gainesville, FL 32610

Tel: 352-273-5485

Fax: 352-273-5515

ORCID: 0000-0002-4636-5780 
medRxiv preprint doi: https://doi.org/10.1101/2021.08.22.21262430; this version posted August 23, 2021. The copyright holder for this preprint (which was not certified by peer review) is the author/funder, who has granted medRxiv a license to display the preprint in perpetuity.

It is made available under a CC-BY-NC-ND 4.0 International license .

Main Text Total word count: $\mathbf{3 , 5 1 7}$

Funding: P.N. is supported by a Hassenfeld Scholar Award from the Massachusetts General Hospital, grants from the National Heart, Lung, and Blood Institute (R01HL1427, R01HL148565, and R01HL148050), and from Fondation Leducq (TNE-18CVD04). S.M.Z is supported by the NIH National Heart, Lung, and Blood Institute (1F30HL149180-01) and the NIH Medical Scientist Training Program Training Grant (T32GM136651). A.G.B. is supported by a Burroughs Wellcome Fund Career Award for Medical Scientists, a NIH Director Early Independence Award (DP5-OD029586) and a NHLBI BioData Catalyst Fellowship (OT3 HL147154-01). J.P.P is supported by a John S LaDue Memorial Fellowship. K.P. is supported by NIH grant 5-T32HL007208-43. J.J.F. is supported by grants RYC-2016-20026 and RTI2018093554-A-I00) from the Spanish "Ministerio de Ciencia e Innovación", a 2019 Leonardo Grant for Researchers and Cultural Creators from the BBVA Foundation, the European Research Area Network on Cardiovascular Diseases CHEMICAL (grant AC19/00133 from the "Spanish Instituto de Salud Carlos III") and the Leducq Foundation (TNE-18CVD04). The project leading to these results received funding from "la Caixa" Foundation (ID 100010434), under agreement HR17-00267. The Centro Nacional de Investigaciones Cardiovasculares (CNIC) is supported by the Instituto de Salud Carlos III (ISCIII), the Ministerio de Ciencia e Innovación and the Pro CNIC Foundation. P.L. receives funding support from the National Heart, Lung, and Blood Institute (1R01HL134892), the American Heart Association (18CSA34080399), the RRM Charitable Fund, and the Simard Fund.

Disclosures: P.N. reported grants from Amgen during the conduct of the study and grants from Boston Scientific; grants and personal fees from Apple; personal fees from Novartis and Blackstone Life Sciences; and spousal employment at Vertex all outside the submitted work. P.L. is an unpaid consultant to, or involved in clinical trials for Amgen, AstraZeneca, Baim Institute, Beren Therapeutics, Esperion, Therapeutics, Genentech, Kancera, Kowa Pharmaceuticals, Medimmune, Merck, Norvo Nordisk, Merck, Novartis, Pfizer, SanofiRegeneron. Dr. Libby is a member of scientific advisory board for Amgen, Corvidia Therapeutics, DalCor Pharmaceuticals, Kowa Pharmaceuticals, Olatec Therapeutics, Medimmune, Novartis, and XBiotech, Inc. P.L.'s laboratory has received research funding in the last 2 years from Novartis, he is on the Board of Directors of XBiotech, Inc, and has a financial interest in Xbiotech, a company developing therapeutic human antibodies. These interests were reviewed and are managed by Brigham and Women's Hospital and Partners HealthCare in accordance with their conflict of interest policies. The other authors do not report any disclosures.

Acknowledgments: Thanks to the participants and staff of the UK Biobank and Mass General Brigham Biobank. UK Biobank analyses were conducted using Application 7089. Thanks to Dr. Zeyan Liew and teaching fellow Jiajun $\mathrm{Lu}$, the instructors of the causal inference course at Yale. 
medRxiv preprint doi: https://doi.org/10.1101/2021.08.22.21262430; this version posted August 23, 2021. The copyright holder for this preprint (which was not certified by peer review) is the author/funder, who has granted medRxiv a license to display the preprint in perpetuity.

It is made available under a CC-BY-NC-ND 4.0 International license .

92 Abstract

93 Background: Somatic mutations in blood indicative of clonal hematopoiesis of indeterminate

94 potential (CHIP), particularly in DNMT3A, TET2, and $J A K 2$, are associated with an increased

95 risk of hematologic malignancy, coronary artery disease, and all-cause mortality. However,

96 whether CHIP is associated with increased risk of peripheral artery disease (PAD) remains

97 unknown. In addition, chemotherapy frequently causes mutations in DNA Damage Repair

98 (DDR) genes TP53 and PPMID, and whether CHIP caused by somatic mutations in DDR genes

99 results in increased risk of atherosclerosis is unclear. We sought to test whether CHIP, and CHIP

100 caused by DDR genes, associates with incident peripheral artery disease (PAD) and

101 atherosclerosis.

102 Methods: We identified CHIP among 50,122 exome sequences in individuals from UK and

103 Mass General Brigham Biobanks and tested CHIP status (N=2,851) with incident PAD and

104 atherosclerosis across multiple arterial beds. To mimic the human scenario of clonal

105 hematopoiesis and test whether the expansion of p53-deficient hematopoietic cells contributes to

106 atherosclerosis, a competitive bone marrow transplantation (BMT) strategy was used to generate

107 atherosclerosis-prone $L d l r-/-$ chimeric mice carrying 20\% Trp53-/- hematopoietic cells (20\%

108 KO-BMT mice). We then evaluated aortic plaque burden and plaque macrophage accumulation

10912 weeks after grafting.

110 Results: CHIP associated with incident PAD (HR 1.7; $\left.\mathrm{P}=2.2 \times 10^{-5}\right)$ and atherosclerosis in

111 multiple beds (HR 1.3; $\left.\mathrm{P}=9.7 \times 10^{-5}\right)$, with increased risk among individuals with DDR CHIP (HR

112 2.0; $\mathrm{P}=0.0084)$. Among atherosclerosis-prone Ldlr null mice, the p53 -/- 20\% KO-BMT mice

113 demonstrated increased aortic plaque size $(\mathrm{p}=0.013)$ and accumulation of $\mathrm{p} 53-/-$ plaque

114 macrophages $(\mathrm{P}<0.001)$, driven by an abundance of $\mathrm{p} 53$-deficient plaque macrophages. The 
medRxiv preprint doi: https://doi.org/10.1101/2021.08.22.21262430; this version posted August 23, 2021. The copyright holder for this preprint (which was not certified by peer review) is the author/funder, who has granted medRxiv a license to display the preprint in perpetuity.

It is made available under a CC-BY-NC-ND 4.0 International license.

115 expansion of p53-deficient cells did not affect the expression of the pro-inflammatory cytokines

116 IL-6 and IL-1 $\beta$ in the atherosclerotic aortic wall.

117 Conclusions: Our findings highlight the role of CHIP as a broad driver of atherosclerosis across

118 the entire arterial system, with evidence of increased plaque among p53 -/- 20\% KO-BMT mice

119 via expansion of plaque macrophages. These observations provide new insight into the link

120 between CHIP and cardiovascular disease, and lend human genetic support to the concept that

121 post-cytotoxic chemotherapy patients may benefit from surveillance for atherosclerotic

122 conditions in addition to therapy-related myeloid neoplasms.

123

124 Abstract Word Count: 346

125 Key Words: somatic, atherosclerosis, clonal hematopoiesis, sequencing 
medRxiv preprint doi: https://doi.org/10.1101/2021.08.22.21262430; this version posted August 23, 2021. The copyright holder for this preprint (which was not certified by peer review) is the author/funder, who has granted medRxiv a license to display the preprint in perpetuity.

It is made available under a CC-BY-NC-ND 4.0 International license .

Introduction

140 Peripheral artery disease (PAD) is a leading cause of cardiovascular morbidity and mortality

141 worldwide, and age is among its strongest risk factors. PAD associates with an extremely high

142 cardiovascular mortality and unmitigated can progress to limb loss ${ }^{1}$. The age-related acquisition

143 and expansion of leukemogenic mutations in hematopoietic stem cells has recently been

144 associated with an increased risk of hematologic malignancy, coronary artery disease, and

145 overall mortality ${ }^{2,3}$. This phenomenon, termed clonal hematopoiesis of indeterminate potential

146 (CHIP), is relatively common in asymptomatic older adults, affecting at least 10\% of individuals

147 older than 70 years of age ${ }^{4}$. CHIP mutations most frequently occur in epigenetic regulators

$148 D N M T 3 A$ and TET2, in DNA damage repair (DDR) genes PPM1D and TP53, or cell cycle and

149 transcriptional regulator genes $J A K 2$ and $A S X L 1^{5}$. CHIP associates with coronary artery disease

150 in multiple studies ${ }^{2,6}$. Whether CHIP links with increased risk of atherosclerosis in the peripheral

151 arterial bed (PAD) is unknown.

152 Here, we leveraged 50,122 whole exome sequences from two genetic biobanks (UK

153 Biobank [UKB], Mass General Brigham Biobank [MGBB]) and tested whether CHIP was

154 associated with increased risk of PAD and atherosclerosis across multiple arterial beds, and

155 additionally whether these associations varied by putative CHIP driver gene. Based on these

156 results, we then performed functional analyses in Ldlr-null mice transplanted with 20\% Trp53-/-

157 bone marrow cells, a murine model of atherosclerosis and clonal hematopoiesis driven by TP53

158 mutations.

160 Methods

161 Cohorts and exclusion criteria 
medRxiv preprint doi: https://doi.org/10.1101/2021.08.22.21262430; this version posted August 23, 2021. The copyright holder for this preprint (which was not certified by peer review) is the author/funder, who has granted medRxiv a license to display the preprint in perpetuity.

It is made available under a CC-BY-NC-ND 4.0 International license .

162 The UKB is a population-based cohort of approximately 500,000 participants recruited from 163 2006-2010 with existing genomic and longitudinal phenotypic data and median 10-year follow-

164 up $^{7}$. Baseline assessments were conducted at 22 assessment centres across the UK with sample 165 collections including blood-derived DNA. Of $\sim 49,960$ individuals with WES data available, we 166 analyzed 37,657 participants consenting to genetic analyses after our exclusion criteria. Use of

167 the data was approved by the Massachusetts General Hospital Institutional Review Board 168 (protocol 2013P001840) and facilitated through UK Biobank Application 7089.

The MGBB contains genotypic and clinical data from $>105,000$ patients who consented

170 to broad-based research across 7 regional hospitals and median 3-year follow-up ${ }^{8}$. Baseline

171 phenotypes were ascertained from the electronic medical record and surveys. We analyzed

17212,465 individuals consenting to genetic analysis after our exclusion criteria. Use of the data was

173 approved by the Massachusetts General Hospital Institutional Review Board (protocol

174 2020P000904).

175

Across both cohorts, we excluded individuals with prevalent hematologic cancer,

176 individuals without genotypic-phenotypic sex concordance, and one of each pair of $1^{\text {st }}$ or $2^{\text {nd }}$

177 degree relatives at random. For the UKB, samples were further restricted to individuals with

178 Townsend deprivation index, a marker of socioeconomic status, available for analysis. Follow-up

179 time was defined as time from enrollment to disease diagnosis for cases, or to censorship or

180 death for controls.

182 Whole exome sequencing and CHIP calling

183 UKB WES were generated from whole blood-derived DNA at the Regeneron Sequencing

184 Center ${ }^{9}$. MGBB WES were generated using whole blood-derived DNA using Illumina 
medRxiv preprint doi: https://doi.org/10.1101/2021.08.22.21262430; this version posted August 23, 2021. The copyright holder for this preprint (which was not certified by peer review) is the author/funder, who has granted medRxiv a license to display the preprint in perpetuity.

It is made available under a CC-BY-NC-ND 4.0 International license .

185 sequencing (mean coverage 55x). Somatic CHIP variants were detected with GATK MuTect2

186 software with parameters as previously described ${ }^{6,10}$. Common germline variants and sequencing

187 artifacts were excluded as before. Samples were annotated with the presence of any CHIP if

188 MuTect2 identified one or more of a pre-specified list of pathogenic somatic variants, as

189 previously described ${ }^{11,12}$. Additionally, samples were annotated with the presence of Large

190 CHIP (variant allele frequency $>10 \%$ ), as larger CHIP clones have previously been more

191 strongly associated with adverse clinical outcomes ${ }^{6}$.

\section{Phenotype definitions}

194 Across both UKB and MGBB, PAD was defined by grouping together ICD-10 and ICD-9 billing

195 codes for aortic atherosclerosis (I70), peripheral vascular disease (I73.8, I73.9), and operative

196 procedures including amputation of leg (X09.3-5), bypass of artery of leg (L21.6, L51.3, L51.6,

197 L51.8, L59.1-8), endarterectomy or angioplasty of leg artery (L52.1-2, L54.1,4,8, L60.1-2,

198 L63.1,5), and other transluminal operations on leg arteries or peripheral stent placement

199 (L63.9,L66.7), as previously described ${ }^{13}$. Additionally, in the UKB self-reported peripheral

200 vascular disease, leg claudication/intermittent claudication, arterial embolism, femoral-popliteal

201 leg artery bypass, leg artery angioplasty +/- stent, or amputation of leg were also incorporated

202 (Data fields 20002, 20004) as performed previously ${ }^{13}$. Coronary artery disease and cerebral

203 atherosclerosis phenotype definitions for each cohort are detailed in Tables I and II in the

204 supplement. Other atherosclerotic conditions were defined using the Phecode Map 1.2 ${ }^{14}$ ICD-9

205 (https://phewascatalog.org/phecodes) and ICD-10 (https://phewascatalog.org/phecodes icd10)

206 phenotype groupings for “abdominal aortic aneurysm”, "aortic aneurysm”, "other aneurysm”,

207 "chronic vascular insufficiency of intestine", "acute vascular insufficiency of intestine", 
medRxiv preprint doi: https://doi.org/10.1101/2021.08.22.21262430; this version posted August 23, 2021. The copyright holder for this preprint (which was not certified by peer review) is the author/funder, who has granted medRxiv a license to display the preprint in perpetuity.

It is made available under a CC-BY-NC-ND 4.0 International license .

"atherosclerosis of renal artery". The composite atherosclerosis phenotype was created by combining all analyzed atherosclerosis phenotypes (including PAD, coronary artery disease,

210 cerebral atherosclerosis, abdominal aortic aneurysm, aortic aneurysm, other aneurysm, chronic

211 vascular insufficiency of intestine, acute vascular insufficiency of intestine, and atherosclerosis

212 of renal artery) into one phenotype, whereby the first instance across all of these phenotypes was

213 used to determine time of first diagnosed atherosclerotic disease for survival analysis. Other

214 phenotypic covariates (never/prior/current smoking status, hypertension, hyperlipidemia,

215 principal components of ancestry, etc.) were used as previously defined ${ }^{15}$.

218 In the UKB and MGBB a traditional cox-proportional hazards model was utilized using the

219 Survival package in R-3.5 adjusting for age, age $^{2}$, sex, smoking status, normalized Townsend

220 deprivation index as a marker of socioeconomic status (only available in UKB), and the first ten

221 principal components of genetic ancestry. Demographic and clinical characteristics found to

222 differ between individuals with and without CHIP were tested using chi-squared (categorical)

223 and Wilcoxon-rank sum (continuous) tests with a two-tailed $\mathrm{P}<0.05$ determining significance.

224 Sensitivity analysis including other covariates (normalized BMI, prevalent hypertension,

225 prevalent Type 2 diabetes, and prevalent hyperlipidemia) was not found to significantly change

226 associations with PAD in the UKB (Figure I in the supplement). Additional sensitivity

227 analyses were utilized in the UKB including propensity score adjustment, as well as a marginal

228 structural cox proportional hazards model estimated through stabilized inverse-probability-

229 treatment-weight (IPTW) ${ }^{16}$ to estimate the total causal effect of CHIP on PAD. Further details of

230 propensity score methods and stabilized IPTW analysis are described in the supplementary 
medRxiv preprint doi: https://doi.org/10.1101/2021.08.22.21262430; this version posted August 23, 2021. The copyright holder for this preprint (which was not certified by peer review) is the author/funder, who has granted medRxiv a license to display the preprint in perpetuity.

It is made available under a CC-BY-NC-ND 4.0 International license .

231 appendix. For our primary outcome PAD, results were combined across the UKB and MGBB

232 using an inverse-variance weighted fixed effects meta-analysis, a two tailed association $\mathrm{P}<0.05$

233 determined statistical significance. In our secondary analysis of CHIP with 10 additional,

234 incident atherosclerotic diseases, a two-tailed Bonferroni $\mathrm{p}$-value threshold of $\mathrm{P}<0.05 / 10=0.005$

235 was used to declare statistical significance.

237 Mice

Animal experiments followed protocols approved by the Institutional Ethics Committee

239 at the Centro Nacional de Investigaciones Cardiovasculares and conformed to EU Directive 86/609/EEC and Recommendation 2007/526/EC regarding the protection of animals used for

241 experimental and other scientific purposes, enforced in Spanish law under Real Decreto

$2421201 / 2005$. All mice were maintained on a 12-h light/dark schedule in a specific pathogen-free

243 animal facility in individually ventilated cages and given food and water ad libitum. C57B1/6J

244 Trp53-/- mice were obtained from the Jackson Laboratory. Ldlr-/- mice carrying the CD45.1

245 isoform of the CD45 hematopoietic antigen were generated by crossing LDLR-KO mice from

246 the Jackson Laboratory and B6.SJL-PtprcaPepcb/BoyCrl mice from Charles River Laboratories.

247 Competitive bone marrow transplantation and atherosclerosis induction in mice

248 CD45.1+ Ldlr-/- recipients were transplanted with suspensions of BM cells containing 20\%

249 CD45.2+ Trp53-/- cells and 80\% CD45.1+ Trp53+/+ cells (20\% KO-BMT mice) or $20 \%$

250 CD45.2+ Trp53+/+ cells and 80\% CD45.1+ Trp53+/+ cells (20\% WT-BMT mice) similar to

251 previous studies ${ }^{17}$ (Figure II in the supplement). BM cells were isolated from femurs and tibias

252 of donor mice after euthanasia. Recipient $L d l r-/-$ mice were exposed to two doses of $450 \mathrm{rad}$

253 three hours apart. After the second irradiation, each recipient mouse was injected 
medRxiv preprint doi: https://doi.org/10.1101/2021.08.22.21262430; this version posted August 23, 2021. The copyright holder for this preprint (which was not certified by peer review) is the author/funder, who has granted medRxiv a license to display the preprint in perpetuity.

It is made available under a CC-BY-NC-ND 4.0 International license .

254 with $10^{7} \mathrm{BM}$ cells i.v. Water was supplemented with antibiotics for 7 days before transplant and

255 for 14 days post-transplant. Mice that did not recover full pre-irradiation body weight 28 days

256 after transplant were excluded from further analysis. Starting four weeks after BMT, mice were

257 fed a high fat high cholesterol (HF/HC) Western diet (Harlan-Teklad, TD.88137, Adjusted

258 Calories Diet; $42 \%$ from fat, $0.2 \%$ cholesterol) to promote hypercholesterolemia and the

259 development of atherosclerosis. Mice were maintained on a $\mathrm{HF} / \mathrm{HC}$ diet for 9 weeks

\section{Quantification of aortic atherosclerosis burden in mice}

262 Mice were euthanized and aortas were removed after in situ perfusion with phosphate-buffered

263 saline injected through the left ventricle of the heart. Tissue fixation was achieved by immersion

264 in $4 \%$ paraformaldehyde in PBS overnight at $4{ }^{\circ} \mathrm{C}$. Aortic tissue was then dehydrated and

265 embedded in paraffin for sectioning. Histological sections comprising the aortic root as

266 determined by the location of the aortic valve leaflets were cut at a thickness of $4 \mu \mathrm{m}$ or $6 \mu \mathrm{m}$.

267 An operator who was blinded to genotype quantified plaque size in aortic root sections by

268 computer-assisted morphometric analysis of microscopy images. For each mouse, atherosclerotic

269 plaque size in aortic root cross-sections was calculated as the average of 5 independent sections

270 separated by $\sim 16 \mu \mathrm{m}$. Atherosclerotic plaque composition was examined by

271 immunohistochemical techniques. Vascular smooth muscle cells were identified with an alkaline

272 phosphatase-conjugated mouse anti-smooth muscle $\alpha$-actin (SMA) monoclonal antibody (clone

273 1A4, SIGMA) and Vector Red Alkaline Phosphatase Substrate (Vector Laboratories).

274 Macrophages were detected with a rabbit anti-Mac2 monoclonal antibody (Santa Cruz

275 Biotechnologies), a biotin-conjugated goat anti-rat secondary antibody and streptavidin-HRP,

276 DAB substrate (all from Vector Laboratories), with hematoxylin counterstaining. Collagen 
medRxiv preprint doi: https://doi.org/10.1101/2021.08.22.21262430; this version posted August 23, 2021. The copyright holder for this preprint (which was not certified by peer review) is the author/funder, who has granted medRxiv a license to display the preprint in perpetuity.

It is made available under a CC-BY-NC-ND 4.0 International license .

277

278

279

280

281

282

283

284

285

286

287

288

289

290

291

292

293

294

295

296

297

298

299

content was determined by a modified Masson's trichrome staining. Microscopy images were analyzed using ImageJ software using the Color Deconvolution plugin. Plasma was collected in EDTA-coated tubes and cholesterol levels were determined using an enzymatic assay

(Cholesterol E, WAKO Diagnostics).

Flow cytometry analyses of blood and tissue samples.

Peripheral blood was obtained from the facial vein and collected into EDTA-coated tubes. Bone marrow cells were flushed out of two femurs and two tibias per mouse. Aortic arches were digested for 45 minutes at $37^{\circ} \mathrm{C}$ in RPMI containing $10 \% \mathrm{FBS}$ and $0.25 \mathrm{mg} / \mathrm{ml}$ Liberase TM (Roche Life Science). Red blood cells were lysed in all samples by treatment with 1X Red Blood Cell Lysis Buffer (eBioscience ThermoFisher) for 5 minutes on ice. Bone Marrow lineagenegative cells were defined as negative for CD11b, Gr-1, Ter119, B220, CD3e and CD127. Bone marrow HSPCs were defined as Lineage-, c-Kit+, Sca1+. Blood classical monocytes were identified as $\mathrm{CD} 45+, \mathrm{CD} 115^{\mathrm{Hi}}, \mathrm{CD} 43^{\mathrm{Lo}}, \mathrm{Ly} 6 \mathrm{c}^{\mathrm{Hi}}$; patrolling monocytes, as CD45+, CD115 ${ }^{\mathrm{Hi}}$, CD43 ${ }^{\mathrm{Hi}}, \mathrm{Ly} 6 \mathrm{c}^{\mathrm{Lo}}$; neutrophils, as CD45+, CD115 ${ }^{\mathrm{Int}}, \mathrm{Ly} 6 \mathrm{~g}+$; T lymphocytes, as CD45+, CD115-, B220-, CD3+; B lymphocytes, as CD45+, CD115-, CD3-, B220+; and aortic macrophages, as CD45+, CD3-, Ly6g-, CD11B+, F4/80Hi. Gating strategies can be found in our previous publications ${ }^{17,18}$. Samples were stained with combinations of biotinylated and/or fluorescently labeled antibodies in PBS with 1\% FBS for $30 \mathrm{~min}$ on ice. The following fluorescent antibodies were used for staining and flow cytometry analysis: eFluor450-conjugated anti-CD45.2, FITCconjugated anti-CD45.2, Pe-Cy7-conjugated anti-CD45.1, FITC-conjugated anti-CD11b, eFluor450-conjugated anti-CD11B, PE-conjugated anti-CD115, PE-eFluor610-conjugated antiCD3, FITC-conjugated anti-CD4 (from eBioscience); APC-Cy7-conjugated anti- B220, PerCP- 
medRxiv preprint doi: https://doi.org/10.1101/2021.08.22.21262430; this version posted August 23, 2021. The copyright holder for this preprint (which was not certified by peer review) is the author/funder, who has granted medRxiv a license to display the preprint in perpetuity.

It is made available under a CC-BY-NC-ND 4.0 International license .

300 Cy5.5-conjugated anti-Ly6G, BV510-conjugated anti-Ly6G, BV711-conjugated anti-CD43, PE-

301 Cy7-conjugated anti-c-Kit, AlexaFluor647-conjugated anti-Sca-1 (from BD Biosciences); PE-

302 conjugated anti-F4/80 (from R\&D Systems); PerCP-Cy5.5-conjugated anti-CD45.1, BV510-

303 conjugated anti-CD8a, PerCP-Cy5.5-conjugated anti-mouse Ki-67 (from BioLegend).

304 Fixation/permeabilization for Ki-67 intracellular staining was achieved using commercially

305 available kits following manufacturer's instructions (Foxp3 Transcription Factor Staining Buffer

306 Set, eBioscience ThermoFisher). Dead cells were excluded from analysis by DAPI staining in

307 unfixed samples and by LIVE/DEAD Fixable Near-IR staining (ThermoFisher Scientific) in

308 fixed samples. BD LSRFortessa and BD FACSymphony Cytometers (BD Bioscience) were used

309 for data acquisition. Data were analyzed with FlowJo Software.

311 Murine macrophage culture and cell cycle analysis

312 Bone marrow-derived macrophages (BMDM) were obtained from suspensions of femoral BM

313 and differentiated for 7 days in the presence of RPMI Medium supplemented with antibiotics,

$31410 \%$ fetal bovine serum and $100 \mathrm{ng} / \mathrm{ml} \mathrm{MCSF}$. For cell-cycle analysis, MCSF concentration in

315 cell culture medium was decreased to $5 \mathrm{ng} / \mathrm{ml}$ for $48 \mathrm{~h}$ to induce progressive synchronization of

316 macrophages in G0 phase (i.e. quiescence) and cell cycle re-entry was induced by treatment with

$317100 \mathrm{ng} / \mathrm{ml}$ MCSF. Macrophages were trypsinized and collected by centrifugation for 5 minutes at

$318300 \mathrm{~g}$. After fixation in $80 \%$ ethanol for $1 \mathrm{~h}$ at $-20^{\circ} \mathrm{C}$, cells were incubated for at least 30 minutes

319 with $50 \mu \mathrm{g} / \mathrm{mL}$ propidium iodide containing $0.25 \mathrm{mg} / \mathrm{mL}$ RNAse A (both from SIGMA).

320 Labelled cells were analyzed in a BD LSRFortessa flow cytometer BD Bioscience and DNA

321 histograms were fitted into cell cycle distributions using ModFit 3.0 software (Verity Software

322 House). 
medRxiv preprint doi: https://doi.org/10.1101/2021.08.22.21262430; this version posted August 23, 2021. The copyright holder for this preprint (which was not certified by peer review) is the author/funder, who has granted medRxiv a license to display the preprint in perpetuity.

It is made available under a CC-BY-NC-ND 4.0 International license .

Gene expression analysis by quantitative real-time PCR (qPCR) and Western Blot.

Total RNA from aortic arch tissue was isolated using Trizol reagent and RNeasy kits (QIAGEN). RNA $(1 \mu \mathrm{g})$ was reverse transcribed with High-Capacity cDNA Reverse Transcription Kit (Applied Biosystems) and qPCR was performed with SYBR ${ }^{\circledR}$ Green PCR Master Mix (Applied Biosystems) in a AB7900 Real time PCR system. Results were analyzed with the $\Delta \Delta \mathrm{Ct}$ method. The average of 36B4 and $\beta$-actin was used as reference for normalization. Primer sequences can be found in our previous publication ${ }^{17}$. For Western Blot analysis of protein levels, protein extracts from cultured macrophages were obtained using ice-cold lysis buffer $(20 \mathrm{mM}$ Tris- $\mathrm{HCl}$ pH 7.5, $150 \mathrm{mM} \mathrm{NaC}, 1 \mathrm{mM}$ NA2EDTA, $1 \mathrm{mM}$ EGTA, 1\% Triton) supplemented with protease and phosphatase inhibitors (Roche Applied Science). Equal amounts of protein lysates were resolved by SDS-PAGE and the following antibodies were used for immunoblotting: anti-p53 (Cell Signaling, \#32532S, dil 1/1000) and HRP anti-alpha tubulin (AbCam, \#ab40742, dil 1/2000). An ImageQuant LAS 4000 biomolecular imaging system (GE Healthcare) was used for image acquisition and the Image J software was used for band densitometric analysis.

\section{Statistical analysis of data in experimental studies}

Data are shown as mean \pm SEM unless otherwise stated. Statistical significance of differences in experiments with two groups and only one variable was assessed by unpaired Student's t tests (with Welch correction for unequal variance when appropriate) or Mann-Whitney U Tests.

Differences in experiments with more than one independent variable were evaluated by two-way analysis of variance (ANOVA) with post-hoc Sidak's multiple comparison tests. All statistical tests were performed using GraphPad Prism software (GraphPad Software Inc.). 
medRxiv preprint doi: https://doi.org/10.1101/2021.08.22.21262430; this version posted August 23, 2021. The copyright holder for this preprint (which was not certified by peer review) is the author/funder, who has granted medRxiv a license to display the preprint in perpetuity.

It is made available under a CC-BY-NC-ND 4.0 International license .

\section{Results}

Study Cohorts and Risk Of Hematologic Malignancy

350 After excluding individuals with a known history of hematologic malignancy at enrollment, we identified 37,657 unrelated individuals from the UKB and 12,465 individuals from MGBB with

352 whole exome sequencing data available for downstream analysis. Using a previously validated

353 somatic variant detection algorithm ${ }^{10}$, we identified 2,194 (5.8\%) and 657 (5.4\%) CHIP carriers

354 in the UKB and MGBB, respectively (Table III in the supplement). Demographic and clinical

355 characteristics of these individuals, stratified by CHIP status, are depicted in Table IV in the

356 supplement. CHIP carriers tended to be older, male, previous smokers, and have a history of

357 coronary artery disease, hypertension, and hyperlipidemia (two-tailed chi-squared and Wilcoxon-

358 rank sum $\mathrm{P}<0.05)$.

359 We first replicated known CHIP associations ${ }^{10}$ with white blood cell (Beta 0.09 SD; 95\%

360 CI 0.05-0.13; $\left.\mathrm{P}=1.6 \times 10^{-5}\right)$, monocyte (Beta 0.05 SD; 95\% CI 0.01-0.09; $\mathrm{P}=0.009$ ), neutrophil

361 (Beta 0.10 SD; 95\% CI 0.06-0.14; $\mathrm{P}=2.1 \times 10^{-6}$ ), and platelet counts (Beta 0.07 SD; 95\% CI 0.03-

$3620.11 ; \mathrm{P}=0.0005)$ in $\mathrm{UKB}$, with larger $\mathrm{CHIP}$ clone size as measured by variant allele fraction

363 (VAF) having stronger effects on blood counts (Figure III in the supplement). Consistent with

364 the existing literature ${ }^{5,10}$, CHIP also associated with incident hematologic malignancy (HR 2.20;

$36595 \%$ CI 1.70-2.85; $\left.\mathrm{P}=1.8 \times 10^{-9}\right)$ - specifically for acute myeloid leukemia (HR 8.08; 95\% CI

366 4.36-14.97; $\left.\mathrm{P}=3.2 \times 10^{-11}\right)$, myeloproliferative neoplasms (HR 5.89; 95\% CI 3.69-9.89; $\mathrm{P}=9.7 \times 10^{-}$

$36{ }^{14}$ ), and polycythemia vera (HR 12.37; 95\% CI 4.85-31.54; $\left.\mathrm{P}=1.4 \times 10^{-7}\right)$. This risk increased with 368 larger VAF (Figure IV in the Supplement). 
medRxiv preprint doi: https://doi.org/10.1101/2021.08.22.21262430; this version posted August 23, 2021. The copyright holder for this preprint (which was not certified by peer review) is the author/funder, who has granted medRxiv a license to display the preprint in perpetuity.

It is made available under a CC-BY-NC-ND 4.0 International license .

371 We next tested the association of CHIP status with incident PAD. Using available electronic

372 health record (EHR) data and a previously validated PAD definition ${ }^{13}$, we identified 338 and 419

373 incident PAD cases in UKB and MGBB, respectively. CHIP associated with a 58\% increased

374 risk of incident PAD in the $\mathrm{UKB}\left(\mathrm{HR}_{\mathrm{UKB}}=1.58,95 \% \mathrm{CI}: 1.11-2.25 ; \mathrm{P}=0.01\right.$, Figure 1), results

375 that were replicated in MGBB (Overall HR $\left.=1.66,95 \% \mathrm{CI}: 1.31-2.11 ; \mathrm{P}=2.4 \times 10^{-5}\right)$. We then

376 sought to evaluate whether those with larger CHIP clone sizes (i.e., higher VAF) had greater risk

377 for PAD, as larger CHIP clones associate more strongly with adverse clinical outcomes ${ }^{6}$. We

378 observed a graded relationship between CHIP VAF and PAD, as those with a VAF $>10 \%$ had

379 even greater risk for an incident PAD event (Overall $\mathrm{HR}=1.97,95 \% \mathrm{CI}: 1.44-2.71 ; \mathrm{P}=2.3 \times 10^{-5}$,

380 Figure 1). Additional sensitivity analyses, including propensity score adjustment and a marginal

381 structural Cox proportional hazards model estimated through stabilized inverse-probability-

382 treatment-weight revealed similar results in the UKB (Figure $\mathbf{V}$ in the supplement). Subsequent

383 analyses showed no significant interaction between CHIP status and either age, sex, or smoking

384 status on incident PAD risk.

385

CHIP and Incident Atherosclerosis Across Multiple Vascular Beds

We next assessed whether CHIP was associated with 9 other incident atherosclerotic

388 diseases across multiple vascular beds. Using EHR-based disease definitions ${ }^{19}$, we tested the

389 association of CHIP with atherosclerotic disease across the mesenteric (acute and chronic),

390 coronary, and cerebral vascular beds, as well as with aneurysmal disease (aortic and any other

391 aneurysm). We observed significant associations for coronary artery disease (HR 1.40, 95\% CI:

3921.20 to $1.63 ; \mathrm{P}=1.9 \times 10^{-5}$ ), any aortic aneurysm (HR $1.74 ; 95 \% \mathrm{CI}: 1.21$ to $\left.2.51 ; \mathrm{P}=0.0028\right)$, other

393 aneurysms (HR 1.70; 95\% CI: 1.23 to $2.34 ; \mathrm{P}=0.0013$ ), and chronic mesenteric ischemia (HR 
medRxiv preprint doi: https://doi.org/10.1101/2021.08.22.21262430; this version posted August 23, 2021. The copyright holder for this preprint (which was not certified by peer review) is the author/funder, who has granted medRxiv a license to display the preprint in perpetuity.

It is made available under a CC-BY-NC-ND 4.0 International license .

9.12; 95\% CI: 2.34 to $35.63 ; \mathrm{P}=0.0015)$ across both cohorts, with directionally consistent effect estimates observed for all the tested phenotypes (Figure 2a). These associations were consistently stronger for large CHIP clones (Figure VI in the supplement). We then created a composite, incident atherosclerosis outcome combining all nine atherosclerotic phenotypes ("pan-arterial atherosclerosis", Table V in the Supplement). CHIP associated with this combined incident pan-arterial atherosclerosis endpoint (HR 1.31, 95\% CI: 1.14 to 1.49 , $\mathrm{P}=9.7 \times 10^{-5}$ ), again with stronger effects conferred by large CHIP clones (HR 1.45; 95\% CI: 1.20 to $1.75 ; \mathrm{P}=0.00013$ ) (Figure $2 \mathbf{b}, \mathbf{c})$.

404 Next, we sought to understand whether the clonal hematopoiesis putative driver gene 405 differentially affected the risk of acquiring atherosclerosis. Previous work has focused primarily 406 on the epigenetic regulators $D N M T 3 A$ and $T E T 2^{3,17}$, and whether DDR CHIP confers an 407 increased risk of atherosclerosis is unknown. We stratified the CHIP-PAD and CHIP pan-arterial 408 atherosclerosis analyses by putative driver genes and specific mutations - focusing on $D N M T 3 A$, 409 TET2, ASXL1, JAK2, the DDR genes PPM1D and TP53, and mutations that specifically disrupt 410 splicing factor genes (LUC7L2, PRPF8, SF3B1, SRSF2, U2AF1, and ZRSR2) ${ }^{20}$. We observed an 411 association of CHIP with PAD across the four common CHIP genes (DNMT3A, TET2, ASXL1, 412 and $J A K 2$ ), with significant heterogeneity of incident PAD effect sizes across the CHIP genes

$413\left(\mathrm{P}_{\text {heterogeneity }}=0.03\right)($ Figure 3a). This heterogeneity persisted in sensitivity analysis after 414 excluding $J A K 2$ carriers $\left(\mathrm{P}_{\text {heterogeneity }}=0.046\right)$. These data also revealed the novel finding that 415 DDR TP53 and PPMID CHIP associates with incident PAD (HR 2.72; 95\% CI: 1.20 to 1.75; $416 \mathrm{P}=0.00013)$ and incident $\mathrm{CAD}(\mathrm{HR} 2.51 ; 95 \% \mathrm{CI}: 1.52-4.14 ; \mathrm{P}=0.00032)$, with a stronger effect 
medRxiv preprint doi: https://doi.org/10.1101/2021.08.22.21262430; this version posted August 23, 2021. The copyright holder for this preprint (which was not certified by peer review) is the author/funder, who has granted medRxiv a license to display the preprint in perpetuity.

It is made available under a CC-BY-NC-ND 4.0 International license .

417 on PAD conferred by TP53 (HR 4.98; 95\% CI: 1.23-20.09; P=0.024, Figure 3a-c). Similar

418 findings were observed for the incident pan-arterial atherosclerosis outcome when stratifying by

419 putative driver gene (Figure VII in the supplement). Further sensitivity analysis for DDR-

420 CHIP and incident PAD when excluding solid organ malignancy did not significantly change the

421 associations $\left(\mathrm{P}_{\text {heterogeneity }}>0.05\right)$.

422

423 Atherosclerosis development in p53-/ CHIP mice

424 Based on our gene specific findings, we next further characterized the effects of reduced function 425 of hematopoietic p53 in atherosclerotic mice. To mimic CHIP and test whether the expansion of 426 p53-deficient hematopoietic cells contributes to atherosclerosis, a competitive bone marrow

427 transplantation (BMT) strategy was used to generate atherosclerosis-prone $L d l r-/-$ chimeric mice 428 carrying 20\% Trp53-/- hematopoietic cells (20\% KO-BMT mice). These mice then consumed a 429 high fat/high cholesterol diet for 9 weeks to induce atherosclerosis development. To distinguish 430 donor Trp53-/- and Trp53+/+ cells in this experimental setting, Trp53+/+ cells were obtained

431 from mice carrying the CD45.1 variant of the CD45 hematopoietic antigen, whereas Trp53-/432 cells were obtained from mice carrying the CD45.2 variant of this protein. Control mice (20\% 433 WT-BMT) were transplanted with 20\% CD45.2+ Trp53+/+ cells and 80\% CD45.1+ Trp53+/+ 434 cells (Figure 4a and Figure II in the supplement). Flow cytometry analysis of CD45.2+ blood 435 cells established that this BMT strategy led to a modest, but significant expansion of donor

436 Trp53-/- BM-derived cells compared to Trp53+/+ cells in both BM hematopoietic

437 stem/progenitor cells (HSPCs) and circulating white blood cells (Figure 4B,C), consistent with

438 previous studies ${ }^{21-23}$. Transplanted Trp53-/- BM cells expanded into all blood cell lineages to a

439 similar extent, but this relative expansion did not affect absolute blood cell counts (Figure VIII 
medRxiv preprint doi: https://doi.org/10.1101/2021.08.22.21262430; this version posted August 23, 2021. The copyright holder for this preprint (which was not certified by peer review) is the author/funder, who has granted medRxiv a license to display the preprint in perpetuity.

It is made available under a CC-BY-NC-ND 4.0 International license .

440 in the supplement). Having validated this mouse model of p53 CHIP based on a competitive

441 BMT strategy, we next assessed whether this phenomenon affects the development of

442 atherosclerosis or related metabolic abnormalities. The presence and expansion of Trp53-/- cells

443 led to a significant $\sim 40 \%$ increase in plaque size in the aortic root of male $\mathrm{Ldlr}$-/- mice (Figure

444 4D), without affecting body weight, spleen weight or serum cholesterol levels (Figure VIII in

445 the supplement, C-E). Similar results were obtained in female $L d l r-/-$ mice (Figure IX in the

446 supplement). In contrast to previous work on DNMT3A/TET2 CHIP, the expansion of p53-

447 deficient cells ${ }^{12,17,18,24,25}$ did not affect the expression of the pro-inflammatory cytokines IL-6

448 and IL-1 $\beta$ in the atherosclerotic aortic wall (Figure $\mathbf{X}$ in the supplement).

Proliferation and expansion of p53-deficient macrophages in the murine atherosclerotic aorta

451 Increased atherogenesis in mice carrying Trp53-/- cells was paralleled by a substantial increase

452 in plaque macrophage content, as assessed by immunohistological staining of Mac2, with no

453 significant changes in other cell components (Figure 5A), suggesting a contribution of increased

454 arterial macrophage burden to accelerated atherosclerosis in conditions of p53 CHIP. Flow

455 cytometry analysis of matched samples from blood and digested atherosclerotic aortae from

$45620 \%$ KO-BMT mice revealed substantially higher chimerism in aortic macrophages ( $76 \%$

457 Trp53-/-) than in blood classical monocytes ( 48\%), the major source of plaque macrophages

458 (Figure 5B). This expansion of p53-deficient macrophages within the vascular wall was

459 paralleled by a 2-fold increase in the frequency of proliferating cells within the CD45.2+ Trp53-

460 /- aortic macrophage population compared to CD45.2+ $\operatorname{Trp} 53+/+$ macrophages, as assessed by

461 flow cytometry analysis of the proliferation-related antigen Ki-67 (Figure 5C). Consistent with

462 our observations in vivo, cultured Trp53-/- macrophages exhibit accelerated mitotic cell cycle 
medRxiv preprint doi: https://doi.org/10.1101/2021.08.22.21262430; this version posted August 23, 2021. The copyright holder for this preprint (which was not certified by peer review) is the author/funder, who has granted medRxiv a license to display the preprint in perpetuity.

It is made available under a CC-BY-NC-ND 4.0 International license .

463 progression, with a $>2$-fold increase in the percentage of S-phase cells upon stimulation with

464 macrophage colony stimulating factor (MCSF), a major determinant of plaque macrophage

465 proliferation ${ }^{26}$ (Figure 5D). Trp53 expression analysis suggests a central role of p53 in the

466 normal regulation of macrophage cell cycle progression, as p53 was expressed in quiescent

467 macrophages at the transcript and protein level and further induced after MCSF stimulation

468 (Figure 5E,F). Furthermore, p53-deficient macrophages exhibited major changes in the

469 expression of pivotal regulators of cell cycle entry and progression, such as $C d k n 1 a / p 21^{\text {Cip } 1}$ and

470 Cyclin B1 (Figure 5G).

471

472 Discussion

473 This study combined exome sequencing data across two biobanks to detect somatic

474 mutations in over 50,000 individuals and observed that the presence of CHIP was significantly

475 associated with an increased risk of developing PAD and atherosclerosis across multiple arterial

476 beds. Increased risk was differentially observed across CHIP driver genes with evidence of a

477 graded relationship with CHIP VAF, with large CHIP clones conferring greater risk of disease.

478 Lastly, analysis of p53 CHIP using a BMT murine model showed increased aortic atherosclerotic

479 plaque among p53 CHIP carriers accompanied by expansion of plaque macrophages, supporting

480 a direct contribution of p53-mutant hematopoietic cells to accelerated atherogenesis.

481 These findings permit several conclusions. First, in humans, CHIP appears to promote

482 atherosclerosis across the entire arterial system. Previous work linked CHIP with increased risk

483 of coronary artery disease and early-onset $\mathrm{MI}^{2,3}$. We build on these findings by demonstrating

484 that CHIP is also associated with PAD, and a composite pan-arterial atherosclerosis outcome

485 reflective of an increased burden of atherosclerosis throughout the human arterial system. In 
medRxiv preprint doi: https://doi.org/10.1101/2021.08.22.21262430; this version posted August 23, 2021. The copyright holder for this preprint (which was not certified by peer review) is the author/funder, who has granted medRxiv a license to display the preprint in perpetuity.

It is made available under a CC-BY-NC-ND 4.0 International license .

addition, we observed suggestive CHIP associations with aneurysmal degeneration of the aorta.

487 The genetic and epidemiologic risk factors underlying atherosclerotic occlusive disease and AAA overlap considerably ${ }^{27}$, and substantial evidence implicates inflammation and macrophage infiltration in driving this aortic disease ${ }^{28}$. The observed link between CHIP and aneurysmal disease warrants further investigation in future studies. coronary artery disease among individuals with CHIP through DNMT3A, TET2, ASXL1, and $J A K 2$ somatic driver mutations ${ }^{3}$. DDR CHIP is often observed among individuals following cytotoxic chemotherapy for the treatment of malignancy and has been linked to the development of therapy-related myeloid neoplasms, but limited evidence is available to inform clinical

497 decision making regarding whether DDR CHIP carriers have increased risk of cardiovascular 498 disease. The current study demonstrates that CHIP related to DDR-genes (TP53, PPM1D) 499 confers an increased risk of developing atherosclerosis. These findings lend human genetic 500 support to the concept that post-cytotoxic chemotherapy patients may benefit from surveillance 501 for atherosclerotic conditions in addition to therapy-related myeloid neoplasms.

503 of p53-deficient macrophages in occlusive plaque lesions. Previous experimental studies

504 assessed the role of p53 in atherogenesis using mice engineered to exhibit gain or loss of

505 function of p53 in the whole body or in specific cell types, with a variety of results ${ }^{29-35}$. Here we 506 demonstrate that carrying a fraction of p53-deficient blood cells is sufficient to accelerate 507 atherosclerosis development, as these cells have a selective advantage to expand, both in HSPCs 508 within the BM and in macrophages within the arterial wall, leading to increased macrophage 
medRxiv preprint doi: https://doi.org/10.1101/2021.08.22.21262430; this version posted August 23, 2021. The copyright holder for this preprint (which was not certified by peer review) is the author/funder, who has granted medRxiv a license to display the preprint in perpetuity.

It is made available under a CC-BY-NC-ND 4.0 International license .

509 burden in the atherosclerotic plaque. Mechanistically, p53-deficient macrophage expansion

510 seems related to increased proliferation, a major driver of macrophage burden in atherosclerotic

511 plaques $^{36}$. Although p53 expression is typically induced by DNA damage or other kinds of

512 cellular stress, we found that it is expressed in resting conditions in cultured macrophages and

513 further induced by mitogenic stimulation, suggesting a physiological role in the regulation of

514 macrophage cell cycle progression. Accordingly, p53-deficient macrophages exhibited

515 accelerated cell cycle kinetics. Overall, these experimental findings provide support to the notion

516 that TP53 CHIP mutations contribute directly to accelerated atherosclerosis and highlight major

517 differences in the mechanisms underlying accelerated atherosclerosis in CHIP driven by

518 mutations in TP53 or epigenetic regulators. Previous murine studies on Tet2 CHIP showed that

519 TET2-deficient cells expand in bone marrow and blood, but not in the atherosclerotic plaque. In

520 contrast, we found that p53 exhibits a double competitive advantage, expanding in both the BM

521 and arterial wall, which suggests that small TP53-mutant blood clones may be sufficient to

522 accelerate atherosclerosis development. Evaluating this possibility will require additional studies

523 using high sensitivity sequencing strategies. Furthermore, in contrast to previous reports related

524 to DNMT3A/TET2 $\mathrm{CHIP}^{12,17,18,24,25}$, we did not observe a significant effect of p53 deficiency on

525 the expression of the pro-inflammatory cytokines IL-1 $\beta$ and IL-6. These results are consistent

526 with previous human data showing that circulating levels of pro-inflammatory cytokines are

527 significantly increased in carriers of CHIP driven by mutations in these epigenetic regulators, but

528 not in carriers of mutations in TP53 or PPMID ${ }^{10}$. These mechanistic differences between TP53-

$529 \mathrm{CHIP}$ and DNMT3A/TET2-CHIP require consideration when designing preventive care strategies

530 targeting the effects of CHIP on atherosclerosis. Thus, while the pathogenic effects of TET2-

531 CHIP may be prevented by targeting IL-1 $\beta$-driven inflammation ${ }^{17}$, accelerated atherosclerosis 
medRxiv preprint doi: https://doi.org/10.1101/2021.08.22.21262430; this version posted August 23, 2021. The copyright holder for this preprint (which was not certified by peer review) is the author/funder, who has granted medRxiv a license to display the preprint in perpetuity.

It is made available under a CC-BY-NC-ND 4.0 International license .

associated with TP53 mutations may be better tackled by other strategies. Additional experimental and clinical studies should evaluate these opportunities for personalized medicine in the context of CHIP.

Lastly, a recent publication has generated a novel hypothesis regarding the relationship between CHIP and atherosclerosis ${ }^{37}$. In their analysis, Heyde et al. suggest that CHIP may be a symptom of the atherosclerosis trait complex (the interplay of chronic inflammation, hyperlipidemia, and arterial plaque), rather than a causal risk factor, based on murine and human observations that atherosclerosis may accelerate HSC proliferation and somatic evolution. While their study engenders an intriguing hypothesis, there are several observations in the literature and in our current study that we believe do not support this interpretation. Firstly, in the Heyde et al. study, Ldlr-null mice irradiated and transplanted with bone marrow of Tet2 -/- mice that were fed an atherogenic diet demonstrated greater Tet2 -/- neutrophil and monocyte expansion than similar mice fed normal chow. However, in marked contrast, we previously showed that Tet2-/cells expand similarly when $L d l r$-null mice are fed either a high cholesterol diet or normal chow $^{17}$. Furthermore, in our prior work, the expansion of Tet2-/- cells was completely unaffected by treatment with a pharmacological NLRP3 inhibitor, even though this inhibitor led to a 2-fold decrease in atherosclerotic plaque size ${ }^{17}$. Secondly, in our current analysis of the pan-arterial atherosclerosis endpoint, CHIP was associated with incident atherosclerotic events among a pool of individuals without any history of atherosclerosis at baseline - suggesting that CHIP precedes clinically significant occlusive disease. Thirdly, Heyde et al. state that the uniform hazard ratios observed for the CHIP-coronary artery disease association provide supportive evidence for the notion that atherosclerotic disease precedes the development of clonal hematopoiesis. However, in our study we identify significant heterogeneity of incident PAD effect sizes when stratifying 
medRxiv preprint doi: https://doi.org/10.1101/2021.08.22.21262430; this version posted August 23, 2021. The copyright holder for this preprint (which was not certified by peer review) is the author/funder, who has granted medRxiv a license to display the preprint in perpetuity.

It is made available under a CC-BY-NC-ND 4.0 International license .

555 by CHIP genes, as well as a dose-response relationship between CHIP clone size (or VAF) and 556 incidence of atherosclerosis, suggesting that CHIP genes vary in their effect on incident PAD

557 risk, and that expanded CHIP variants have a stronger influence on future atherosclerotic risk.

558 Thus, given the 1) association with incident atherosclerotic disease, 2) dose-response relationship

559 with CHIP clone size and heterogeneity by CHIP gene, and 3) that TP53, TET2, and JAK2 38

560 appear to drive atherosclerosis through disparate mechanisms, clonal hematopoiesis acting as a

561 causal risk factor appears to be a more parsimonious explanation to unify these findings.

Several limitations merit mention. First, our PAD and cardiovascular disease phenotypes

563 are based on EHR data and may result in misclassification of case status. Such misclassification

564 would likely reduce statistical power for discovery and on average bias results toward the null.

565 Second, selection bias from differential loss-of-follow up, volunteer bias, and missingness in

566 covariates may be present given the nature of the genetic biobanks used in this study. Third,

567 while we maximized the number of participants in our analysis of CHIP and additional

568 atherosclerotic diseases, it may still have been underpowered for certain phenotypes. Lastly, the

569 cohorts in these studies are largely of European ancestry; while prior reports have not observed

570 significant phenotypic differences in CHIP associations by ancestry ${ }^{5,12}$, further epidemiological

571 studies in ethnically diverse individuals are required to ensure that this is the case for PAD as

572 well.

573 In conclusion, CHIP is associated with incident atherosclerosis in multiple vascular beds,

574 with murine evidence of increased plaque among TP53 CHIP carriers through an expansion of

575 plaque macrophages (Figure 6). The observations presented here expand insight into CHIP-

576 mediated atherosclerosis. The novel finding that DDR gene CHIP plays a particular role in PAD

577 raises new questions regarding the mechanisms of regional heterogeneity of atherosclerotic 
medRxiv preprint doi: https://doi.org/10.1101/2021.08.22.21262430; this version posted August 23, 2021. The copyright holder for this preprint (which was not certified by peer review) is the author/funder, who has granted medRxiv a license to display the preprint in perpetuity.

It is made available under a CC-BY-NC-ND 4.0 International license.

578 involvement in face of systemic exposure to traditional risk factors such as dyslipidemia,

579 hypertension, and smoking. 
medRxiv preprint doi: https://doi.org/10.1101/2021.08.22.21262430; this version posted August 23, 2021. The copyright holder for this preprint (which was not certified by peer review) is the author/funder, who has granted medRxiv a license to display the preprint in perpetuity.

It is made available under a CC-BY-NC-ND 4.0 International license .

a.

582

583

584

585

586

587

588

589

590

591

592

593

594

595

596

597

598

599

600

601

602

603

604

605

606

607

608

609

610

611

612

613

614

615

616

617

618

619

620

621

622

623

624

625
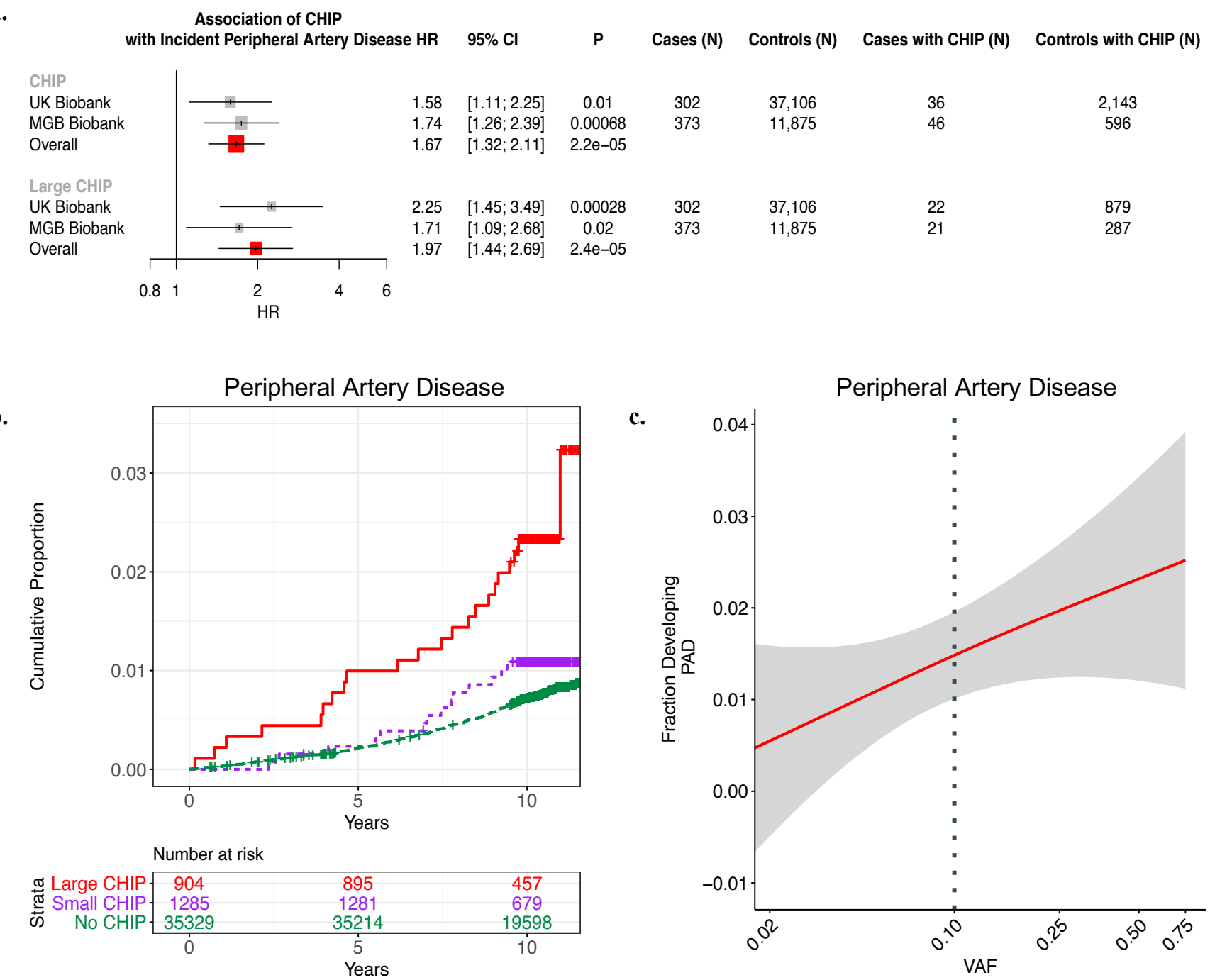

Figure 1. CHIP and incident PAD risk. a) Association of CHIP and large CHIP (VAF>10\%) carrier state with incident PAD events in the UK Biobank (UKB) and Mass General Brigham Biobank (MGBB). Results were combined using an inverse-variance weighted fixed effects meta-analysis. b) Cumulative proportion of individuals developing PAD stratified by CHIP VAF clone size category in the UK Biobank. c) Fraction of individuals developing incident PAD by CHIP VAF in the UK Biobank. CHIP = clonal hematopoiesis of indeterminate potential; VAF = variant allele fraction; $\mathrm{PAD}=$ peripheral artery disease 
medRxiv preprint doi: https://doi.org/10.1101/2021.08.22.21262430; this version posted August 23, 2021. The copyright holder for this preprint (which was not certified by peer review) is the author/funder, who has granted medRxiv a license to display the preprint in perpetuity.

It is made available under a CC-BY-NC-ND 4.0 International license.
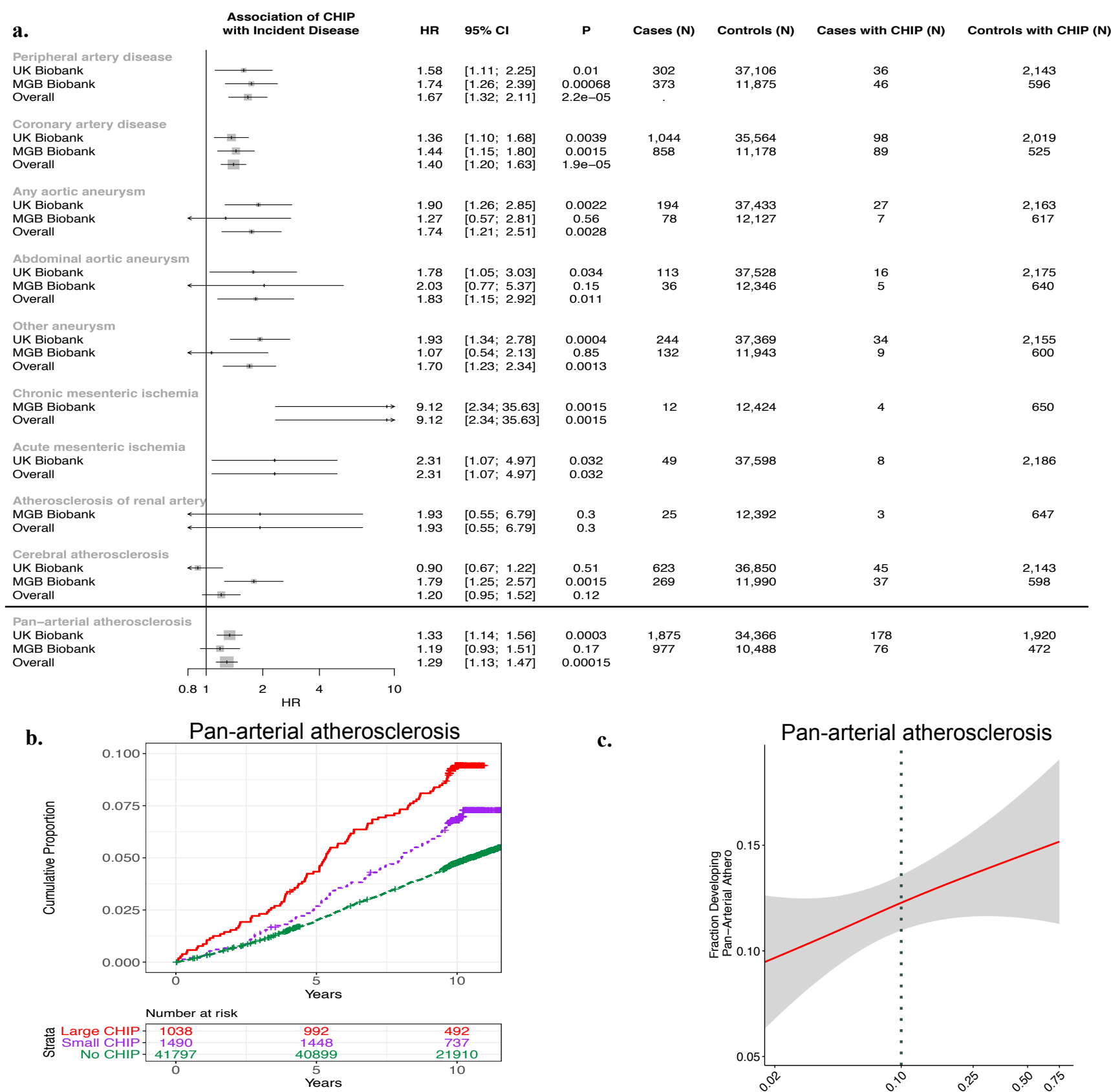

c.

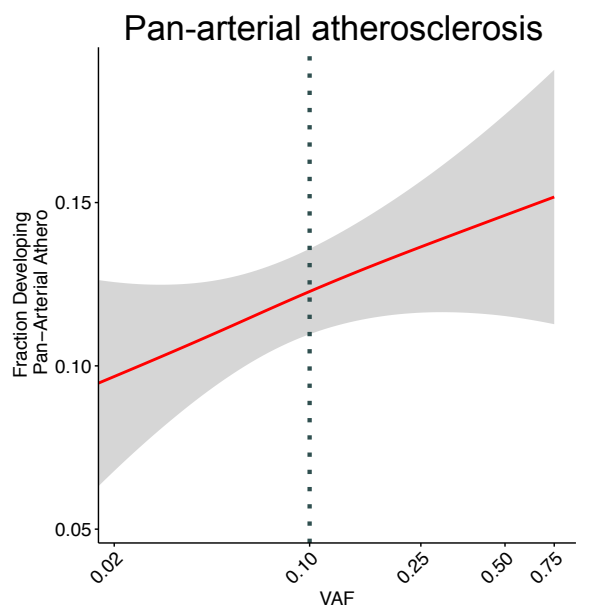

626

627

628

629

630

631

632

633

634

Figure 2. CHIP and incident pan-arterial atherosclerosis risk. a) Association of CHIP with 9 incident atherosclerotic diseases separately and combined in a 'Pan-arterial atherosclerosis' phenotype in the UKB, MGBB, and meta-analyzed across both studies ("Overall"). b) Cumulative risk of incident atherosclerosis across the composite 'pan-arterial atherosclerosis' phenotype stratified by no CHIP, small CHIP $(\mathrm{VAF}<10 \%)$, and large CHIP $(\mathrm{VAF} \geq 10 \%)$ carrier state in the UK Biobank. c) Association of CHIP VAF with fraction of individuals developing pan-arterial atherosclerosis in the UK Biobank. CHIP $=$ clonal hematopoiesis of indeterminate potential; $\mathrm{VAF}=$ variant allele fraction; $\mathrm{PAD}=$ peripheral artery disease 
medRxiv preprint doi: https://doi.org/10.1101/2021.08.22.21262430; this version posted August 23, 2021. The copyright holder for this preprint (which was not certified by peer review) is the author/funder, who has granted medRxiv a license to display the preprint in perpetuity.

a.

It is made available under a CC-BY-NC-ND 4.0 International license.

635

636

637

638

639

640

641

642

643

644

645

646

647

648

649

650

651

652

653

654

655

656

657

658

659

660

661

662

663

664

665

666

667

668

669

Peripheral artery disease
DNMT3A
TET2
ASXL1
Splicing Factor Mutation
PPM1D
TP53
JAK2
Heterogeneity: $p=0.033$

b.

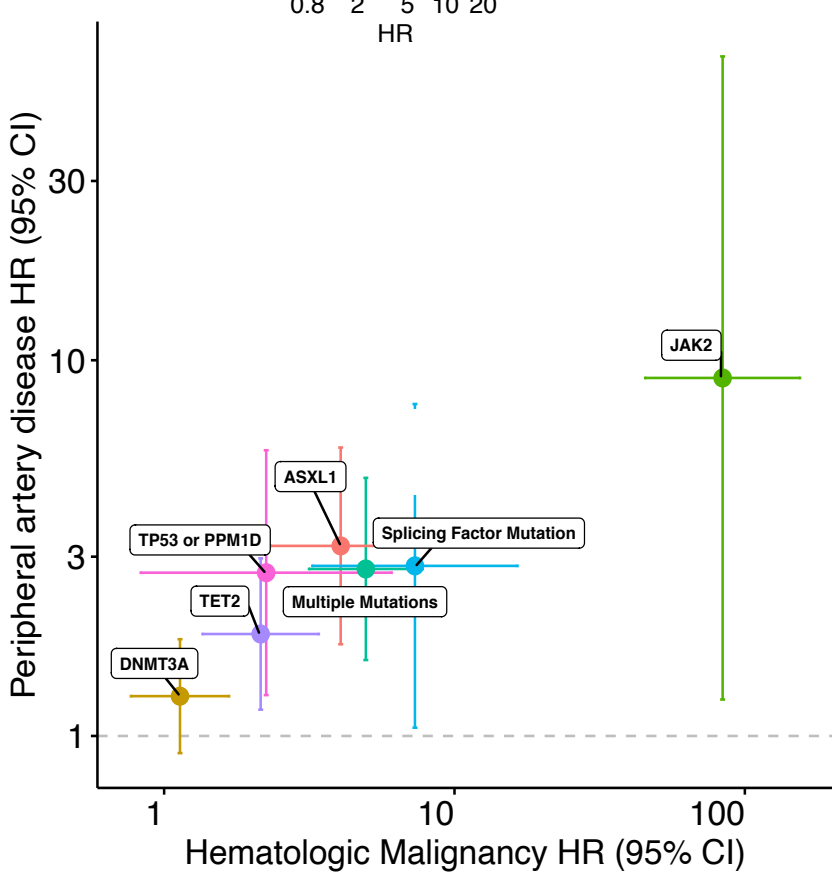

c.

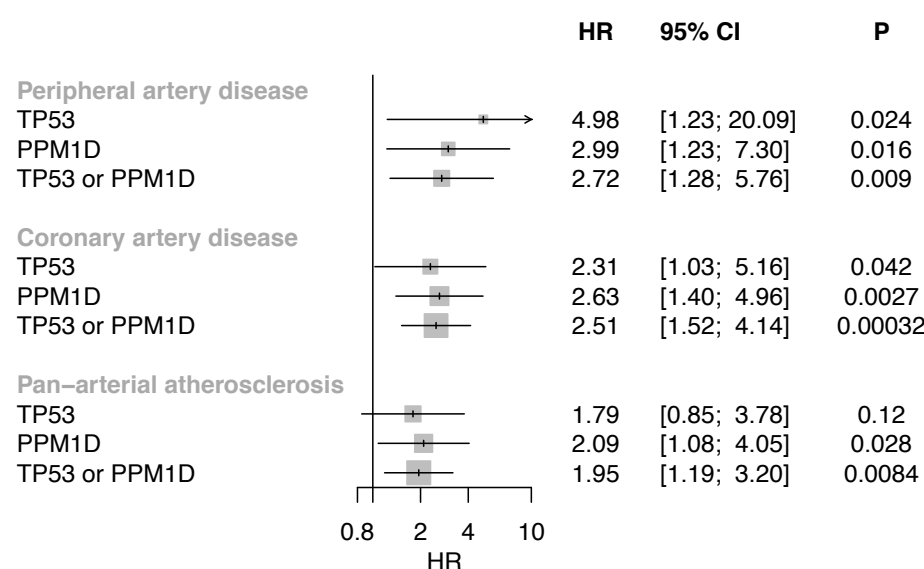

Figure 3: Gene-specific association of CHIP with incident peripheral artery disease (PAD). a) CHIP-PAD association analyses stratified by putative CHIP driver gene. Results following meta-analysis across the UKB and MGBB are shown. b) Gene-specific comparison of HR and 95\% CI for hematologic malignancy (x-axis) and PAD (y-axis) in the UKB. c) Association of DDR CHIP (PPMID or TP53) with incident peripheral artery disease, coronary artery disease, and pan-vascular atherosclerosis. Results across UK Biobank and MGB Biobank were combined using an inverse-variance weighted fixed effects meta-analysis. CHIP = clonal hematopoiesis of indeterminate potential; $\mathrm{DDR}=\mathrm{DNA}$-damage repair; $\mathrm{VAF}=$ variant allele fraction; $\mathrm{PAD}=$ peripheral artery disease 
a.

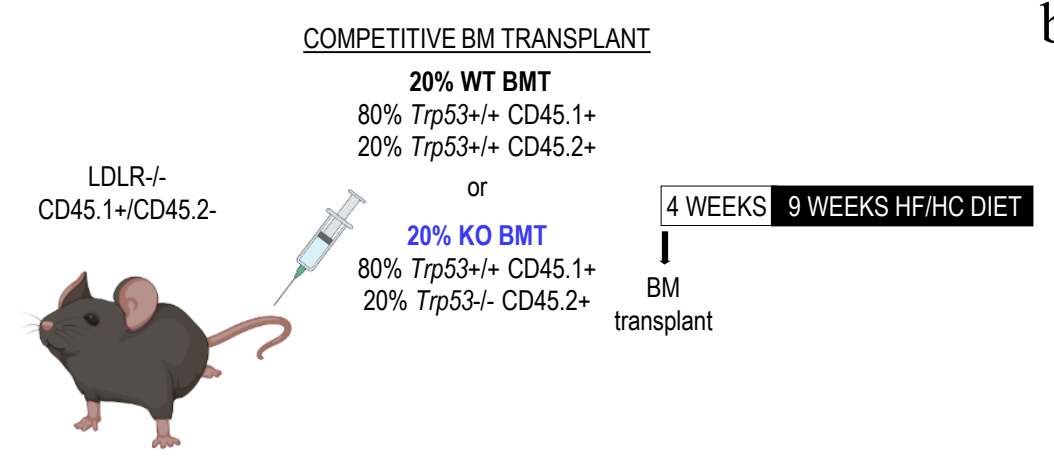

b.

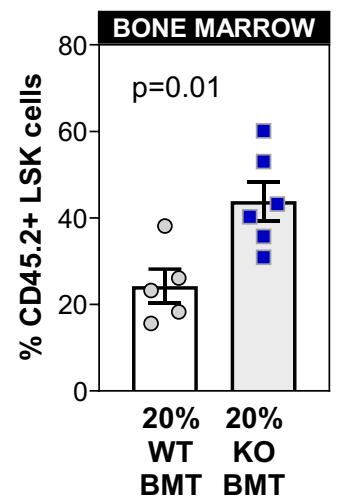

c.

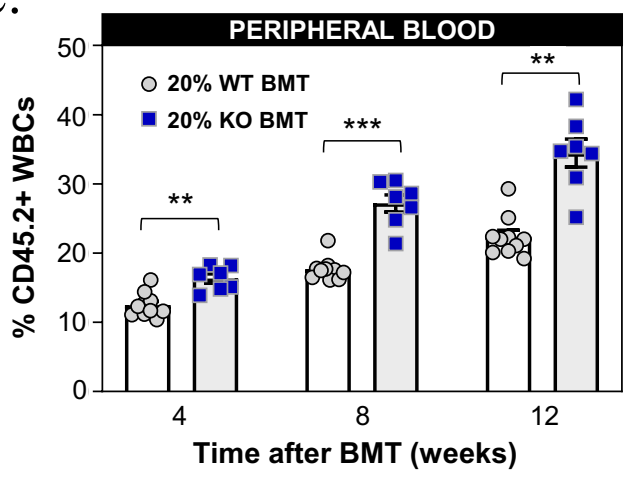

d.
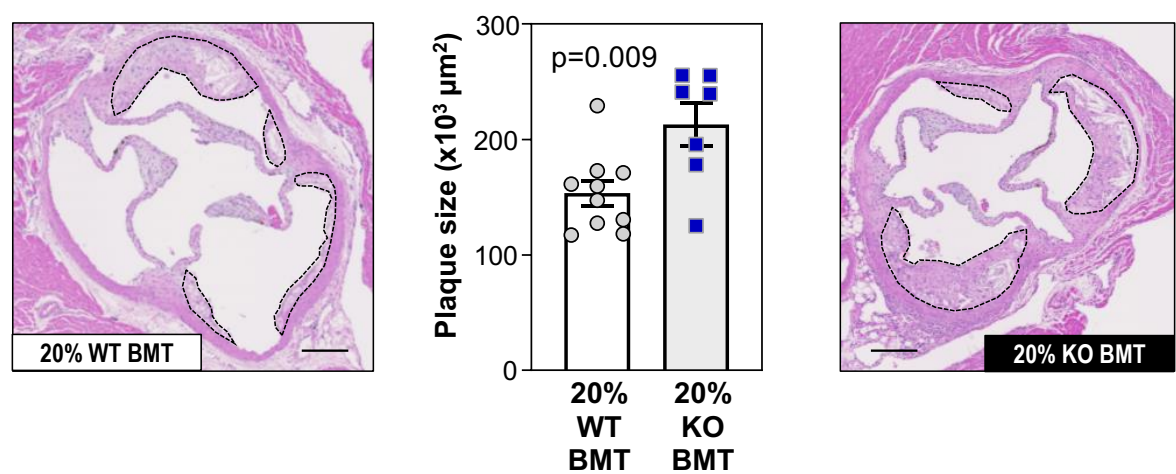

671 Figure 4: Accelerated atherosclerosis in a murine model of TP53 mutation-driven CHIP.

672 a) Summary of the competitive BMT approach and the timeline of these studies. $20 \%$ KO-BMT 673 male mice and 20\% WT-BMT controls were fed a high-fat/high-cholesterol (HF/HC) diet for 9 674 weeks, starting 4 weeks after BMT ( $\mathrm{n}=10$ 20\% WT-BMT, $\mathrm{n}=720 \%$ KO-BMT, unless otherwise 675 noted). b) Percentage of CD45.2+ cells in the bone marrow HSPC population (Lin- Sca1+ cKit+ 676 cells) after 9 weeks on $\mathrm{HF} / \mathrm{HC}$ diet ( 13 weeks post-BMT), evaluated by flow cytometry $(\mathrm{n}=5$ $67720 \%$ WT-BMT, $\mathrm{n}=620 \%$ KO-BMT). c) Percentage of CD45.2+ in white blood cells, evaluated 678 by flow cytometry $\left({ }^{* *} \mathrm{p}<0.01,{ }^{* * *} \mathrm{p}<0.001\right)$. Representative CD45.1/CD45.2 dot plots are shown. 679 d) Aortic root plaque size. Representative images of hematoxylin and eosin-stained sections are 680 shown; atherosclerotic plaques are delineated by dashed lines. Scale bars, $100 \mu \mathrm{m}$. 
a.

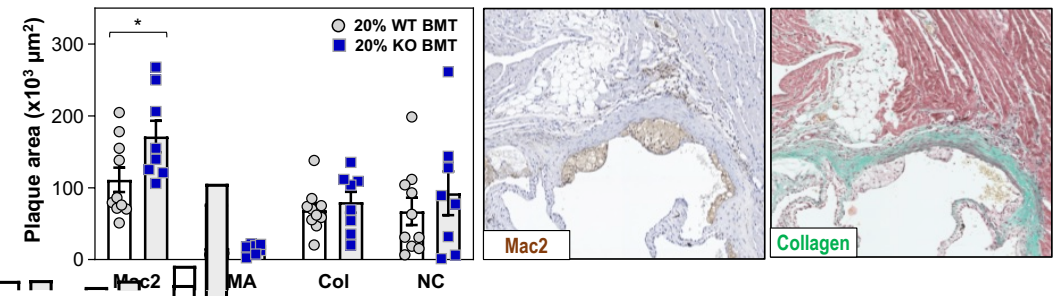

b.

C.
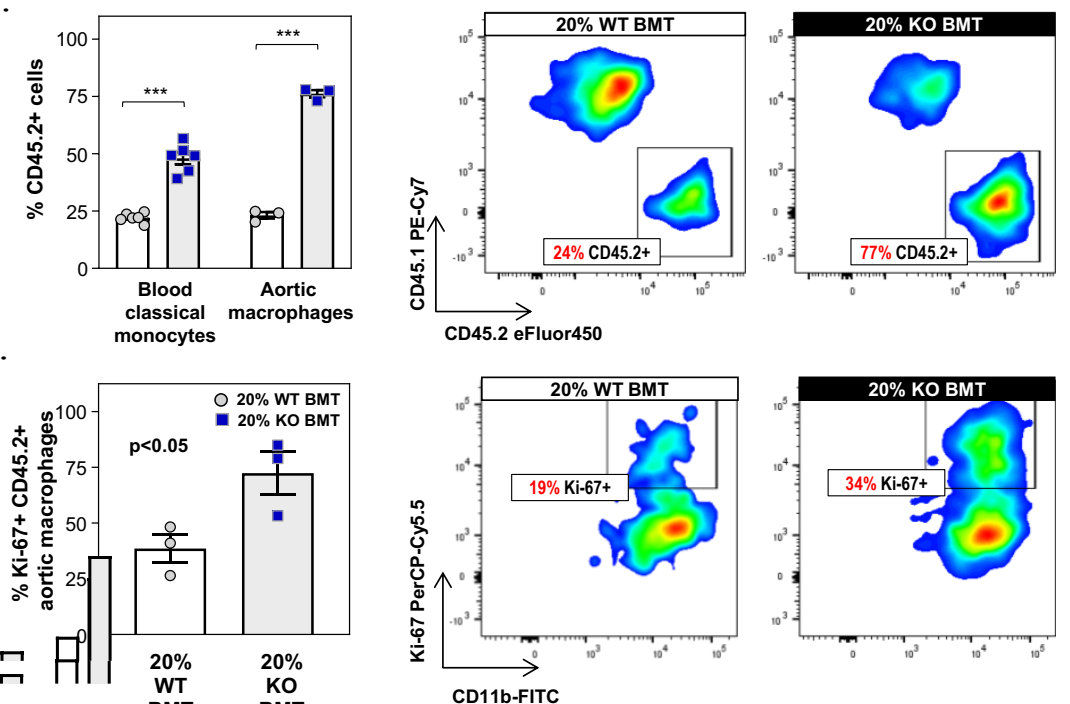

d.

$\begin{array}{ll}\text { WT } & \text { KO } \\ \text { BMT } & \text { BMT }\end{array}$
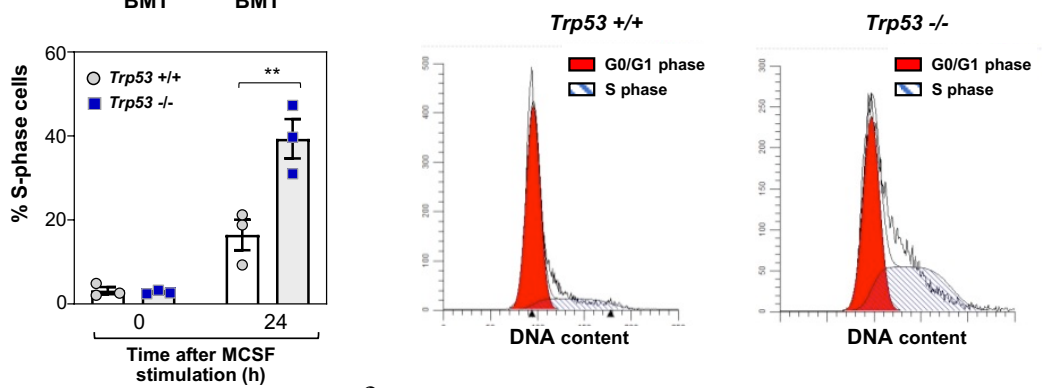

e.

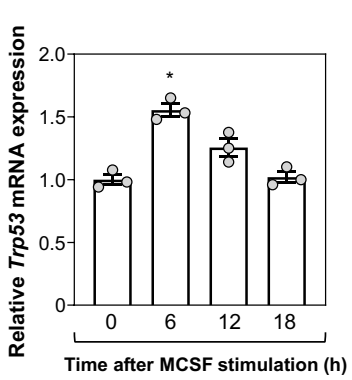

f.

g.
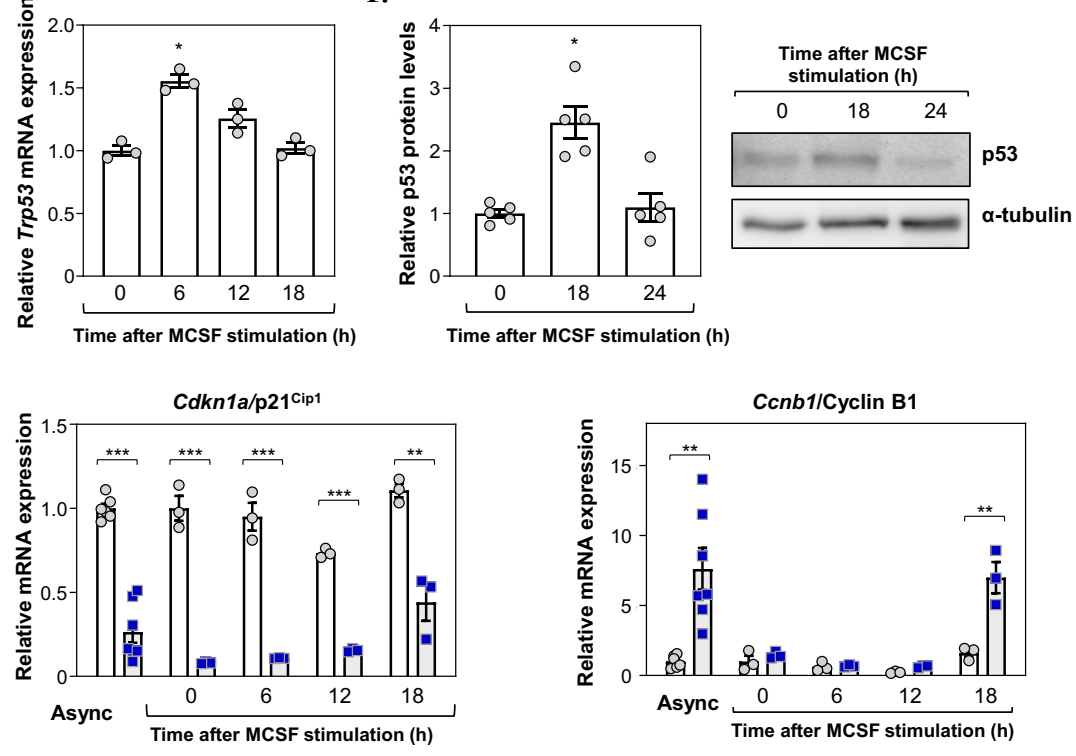
medRxiv preprint doi: https://doi.org/10.1101/2021.08.22.21262430; this version posted August 23, 2021. The copyright holder for this preprint (which was not certified by peer review) is the author/funder, who has granted medRxiv a license to display the preprint in perpetuity.

It is made available under a CC-BY-NC-ND 4.0 International license .

682 Figure 5: Increased proliferation and expansion of p53-deficient macrophages. a) Plaque

683 composition in 20\% KO BMT female mice $(n=10)$ and controls $(n=8)$ quantified as absolute

684 intimal content of macrophages (Mac2 antigen immunostaining), vascular smooth muscle cells

685 (smooth muscle $\alpha$-actin, SMA immunostaining), collagen (Masson's trichrome staining) and

686 necrotic core (collagen-free acellular regions). Representative images of Mac2- and collagen-

687 stained histological sections of 20\% KO BMT mice are shown. b) Percentage of CD45.2+ cells

688 within the aortic macrophage population (CD3-, Ly6g-, CD11B+, F4/80 $\mathrm{Hi}, \mathrm{n}=3$ pools of two

689 aortic arches per BM genotype) and blood classical monocytes (CD3-, CD115 ${ }^{\mathrm{Hi}}$, Ly6g-, CD43 ${ }^{\mathrm{Lo}}$,

690 Ly $6 \mathrm{c}^{\mathrm{Hi}}, \mathrm{n}=6$ per BM genotype) of $20 \%$ KO BMT mice and controls, evaluated by flow

691 cytometry. Representative CD45.1/CD45.2 plots of aortic macrophages are shown. c) Percentage

692 of $\mathrm{Ki}-67+$ proliferating cells within the aortic CD45.2+ macrophage population of $20 \% \mathrm{KO}$

693 BMT mice and controls $(\mathrm{n}=3$ pools of two aortic arches per BM genotype), evaluated by flow

694 cytometry. Representative plots are shown. d) \% of S-phase cells in cultures of Trp53-/- and +/+

695 murine bone marrow-derived macrophages, evaluated by propidium iodide staining of cellular

696 DNA content and flow cytometry; treatment with MCSF was used to induce cell cycle entry and

697 progression in quiescent G0-synchronized macrophages (a representative experiment with

698 macrophages from $n=3$ mice per genotype is shown). e, f) qPCR (e) and Western Blot (f)

699 analyses of Trp53 expression in cultured macrophages after MCSF mitogenic stimulation. p53

700 protein levels were normalized to $\alpha$-tubulin. A representative blot is shown. g) Expression of cell

701 cycle regulators $C d k n 1 a / p 21^{\text {Cip } 1}$ and $C c n b 1 / C y c l i n$ B1 in cultured Trp53-/- and +/+ macrophages

702 proliferating asynchronously (Async) or after MCSF stimulation. ${ }^{*} \mathrm{p}<0.05,{ }^{*} \mathrm{p}<0.01$,

$703 * * * \mathrm{p}<0.001$. 
medRxiv preprint doi: https://doi.org/10.1101/2021.08.22.21262430; this version posted August 23, 2021. The copyright holder for this preprint (which was not certified by peer review) is the author/funder, who has granted medRxiv a license to display the preprint in perpetuity.

It is made available under a CC-BY-NC-ND 4.0 International license .

704
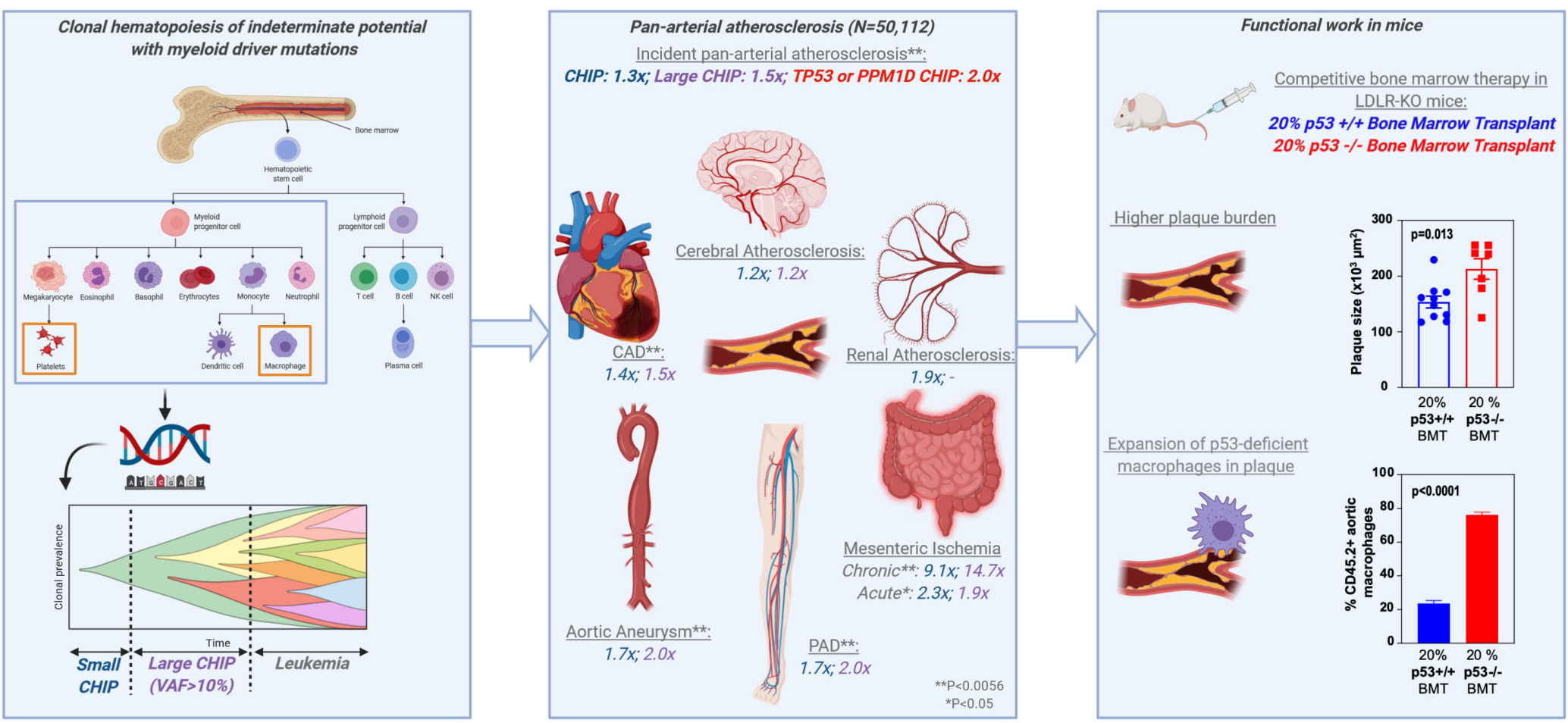

705

706

707

708

Figure 6. In this study, we assessed the association of clonal hematopoiesis of indeterminate

709 potential (CHIP) with myeloid driver mutations with pan-arterial atherosclerosis. CHIP is a category of age-related somatic variants which are associated with incident leukemia and thought

711 to be implicated in atherosclerosis primarily by altering macrophage function and promoting thrombosis. CHIP clones can be characterized by the fraction of blood cells carrying the clone, referred to as the variant allele fraction (VAF); here we categorized large CHIP clones as variants with $\mathrm{VAF}>10 \%$. Across 50,112 individuals from the UK Biobank and Mass-General Brigham Biobank, we observed that CHIP is associated with increased risk of incident peripheral and pan-arterial atherosclerosis, with stronger effects conferred by large CHIP clones (HR 1.5x). In addition, we observed and a novel associations for TP53 and PPM1D CHIP (HR 2.0x). CHIP was found to be individually associated with a variety of atherosclerotic conditions, with Bonferroni-significant associations (double-starred, **) identified for peripheral artery disease (PAD), coronary artery disease (CAD), aortic aneurysm, and chronic mesenteric ischemia. HR for CHIP are displayed in blue and for large CHIP in purple. Functional analysis was performed to further investigate the observed TP53-PAD association. Ldlr-KO 20\% p53 -/- bone-marrow deficient macrophages in plaque $(\mathrm{P}<0.001)$ at 12 weeks. 


\section{CHIP}

Unadjusted Sparsely Adjusted Fully Adjusted

\section{Large CHIP}

Unadjusted Sparsely Adjusted Fully Adjusted

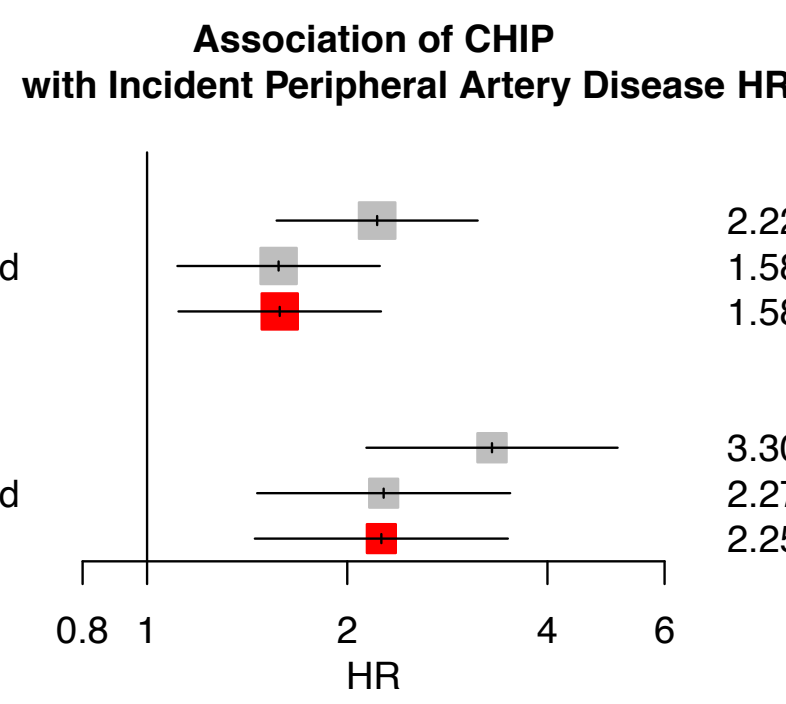

$95 \% \mathrm{Cl}$

[1.57; 3.14]

[1.11; 2.24]

$[1.11 ; 2.25]$

7.3e-06

0.011

0.01

$\begin{array}{ll}{[2.14 ; 5.10]} & 7.3 e-08 \\ {[1.46 ; 3.52]} & 0.00025 \\ {[1.45 ; 3.49]} & 0.00028\end{array}$

Supplementary Figure I. Association of CHIP and Large CHIP (variant allele fraction $>10 \%$ ) with PAD in the UKB under 1) unadjusted, 2) sparsely adjusted, and 3) fully adjusted models, where sparsely adjusted refers to the following covariates: age, age ${ }^{2}$, sex, smoking status, Townsend deprivation index, and the first ten principal components of genetic ancestry, and the fully adjusted model additionally includes normalized BMI, prevalent hypertension, hyperlipidemia, and type 2 diabetes as covariates. Given the minimal difference between the sparsely adjusted and fully adjusted model, the sparsely adjusted model was moved forward for use in analysis. 
BM DONORS
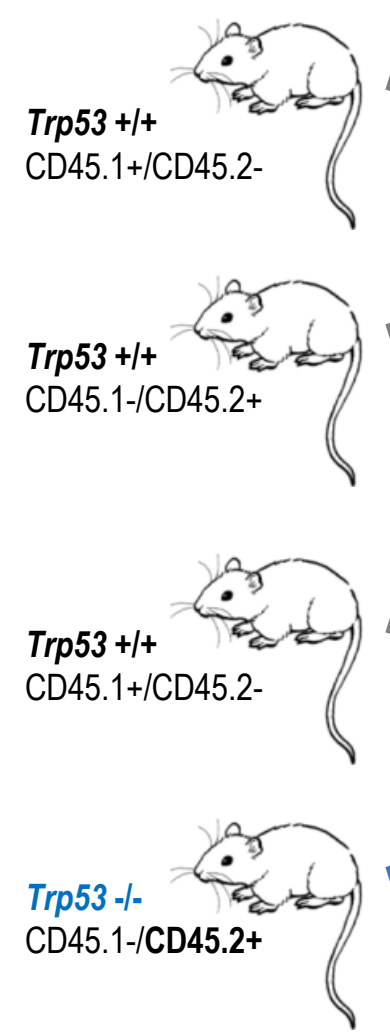

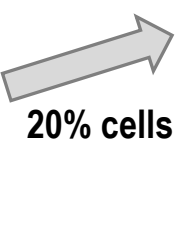

RECIPIENTS

\section{$80 \%$ cells}

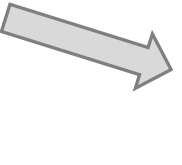

$80 \%$ cells

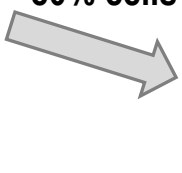

$20 \%$ cells

LdIr-l- $\quad$ V

Supplementary Figure II. Competitive bone marrow transplantation approach to generate a 775

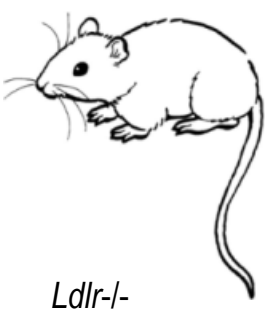

CD45.1+/CD45.2-

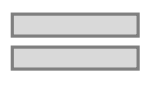

Ldlr-/- mice

80\% +/+ CD45.1+/CD45.2-BM

$20 \%+/+$ CD45.1-/CD45.2+ BM
CHIMERAS
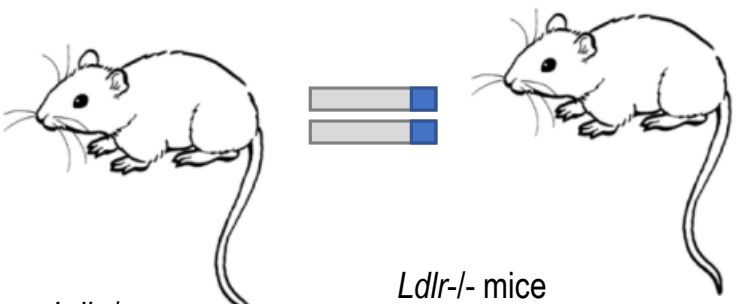

Ldir-l- mice

$80 \%+/+$ CD $45.1+/ C D 45.2-$ BM

$20 \%=-$ CD $45.1-/ C D 45.2+B M$ murine model of p53 CHIP 
medRxiv preprint doi: https://doi.org/10.1101/2021.08.22.21262430; this version posted August 23, 2021. The copyright holder for this preprint (which was not certified by peer review) is the author/funder, who has granted medRxiv a license to display the preprint in perpetuity.

It is made available under a CC-BY-NC-ND 4.0 International license .

a.

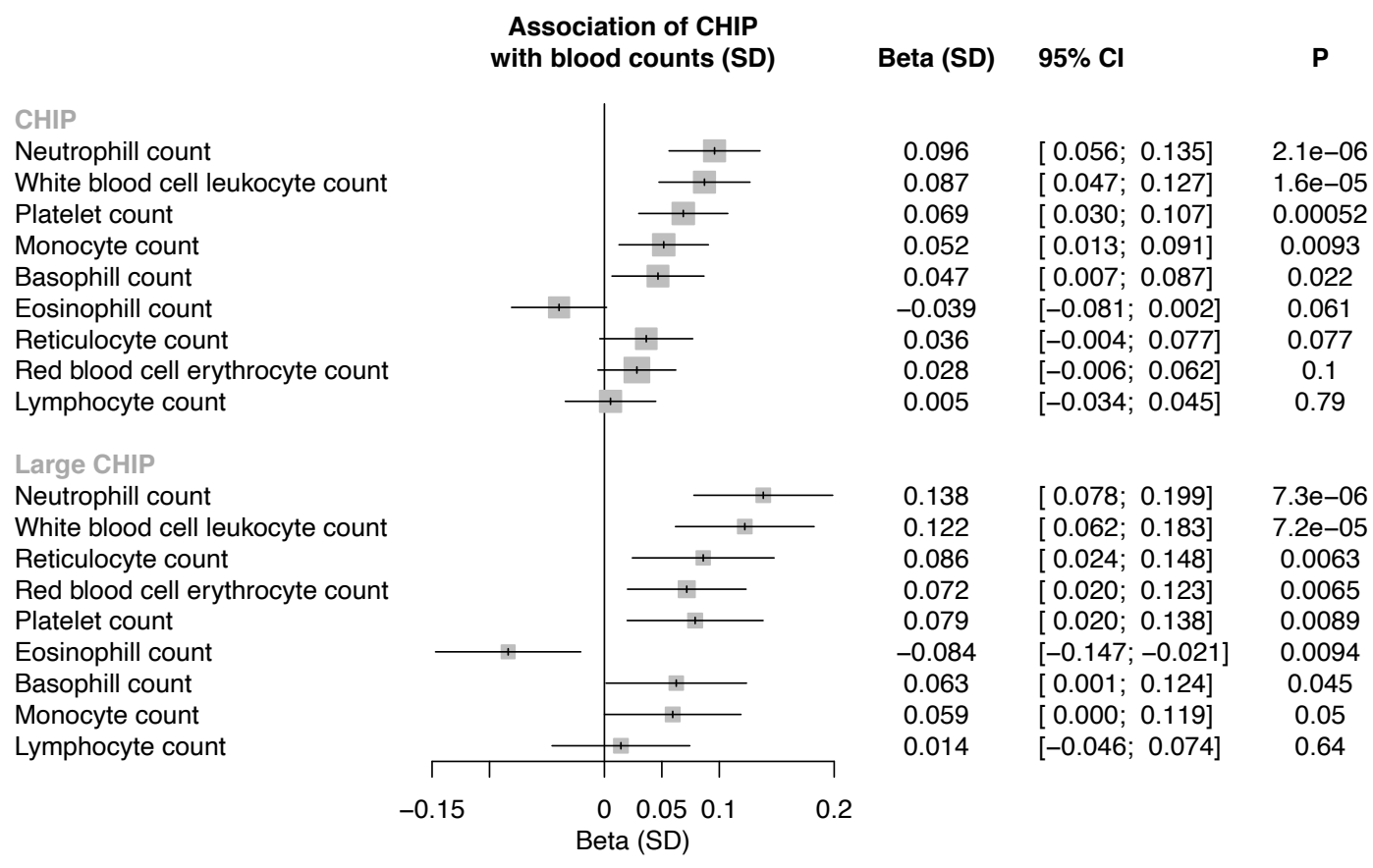

b.
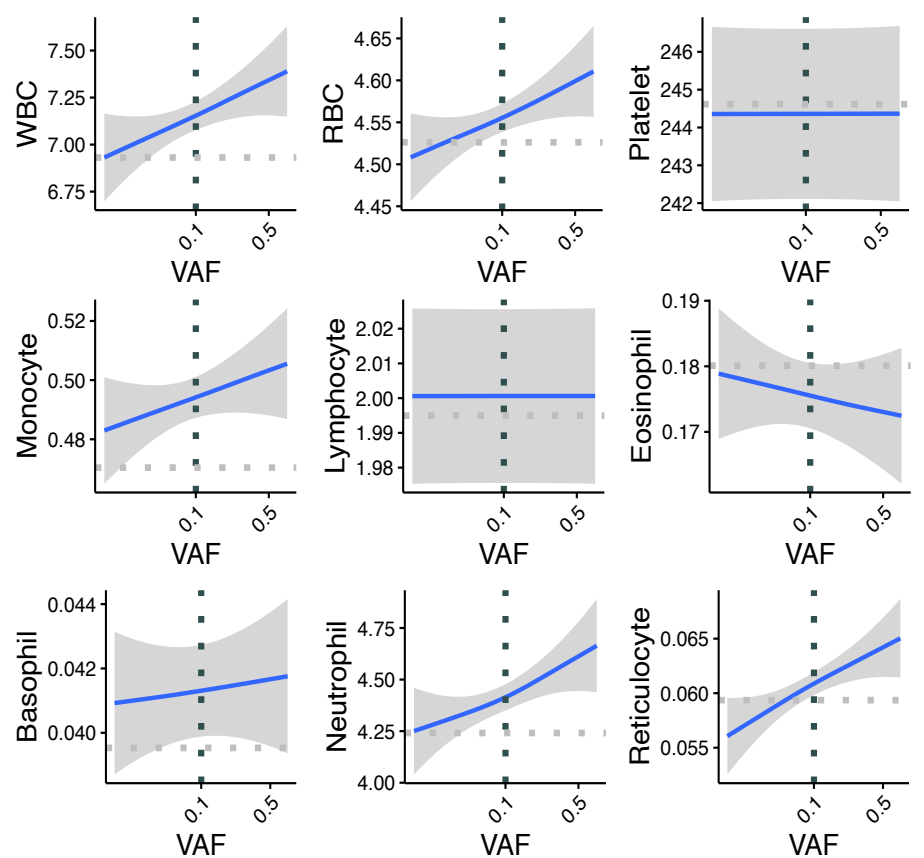

Supplementary Figure III. Association of CHIP with blood counts among individuals without prevalent hematologic malignancy in the UK Biobank. Blood counts were acquired at time of blood draw for whole exome sequencing. a) Association of CHIP and Large CHIP with normalized blood counts (SD). Associations are adjusted for age, age ${ }^{2}$, sex, smoking status, and the first ten principal components of genetic ancestry. b) Association of CHIP variant allele frequency (VAF) with blood counts (in units of $10^{\wedge} 9$ cells/L). The gray horizontal dotted lines reflect average counts across non-CHIP carriers. The vertical black dotted line reflects the cutoff $\mathrm{VAF}$ for Large CHIP (VAF $>0.1)$. CHIP = clonal hematopoiesis of indeterminate potential; VAF $=$ variant allele fraction 
a.

Polycythemia Vera

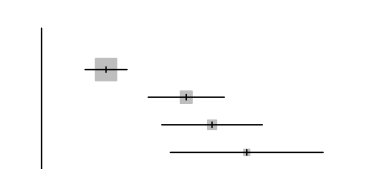

HR

$95 \% \mathrm{Cl}$
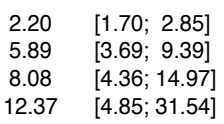

$1.8 e-09$
$9.7 e-14$
$3.2 e-11$

Cases (N)

Controls (N)

Cases with CHIP (N)

Controls with CHIP (N)

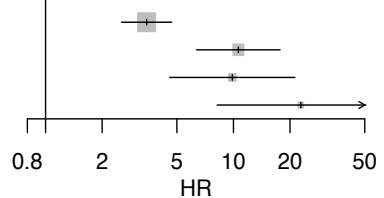

$3.45 \quad[2.54 ; 4.70] \quad 3 e-15$

$10.62 \quad[6.37 ; 17.72] \quad 1.4 \mathrm{e}-19$

$9.86 \quad[4.58 ; 21.24] \quad 5 \mathrm{e}-09$

$22.84 \quad[8.19 ; 63.72] \quad 2.3 \mathrm{e}-09$

$\begin{array}{cc}478 & 37,179 \\ 84 & 37,573 \\ 45 & 37,612 \\ 19 & 37,638\end{array}$

46

b
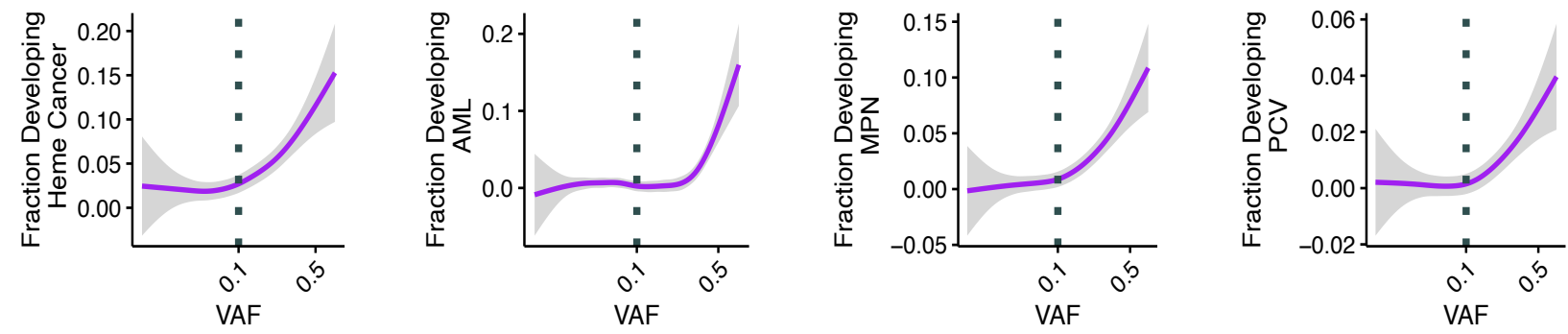

841

842

843

Supplementary Figure IV: Association of CHIP (a) and VAF (b) with incident hematologic malignancy among individuals without prevalent hematological malignancy in the UK Biobank.

848 Associations are adjusted for age, age ${ }^{2}$, sex, smoking status, Townsend deprivation index, and the first ten principal components of genetic ancestry. CHIP = clonal hematopoiesis of indeterminate potential; VAF $=$ variant allele fraction 
a.
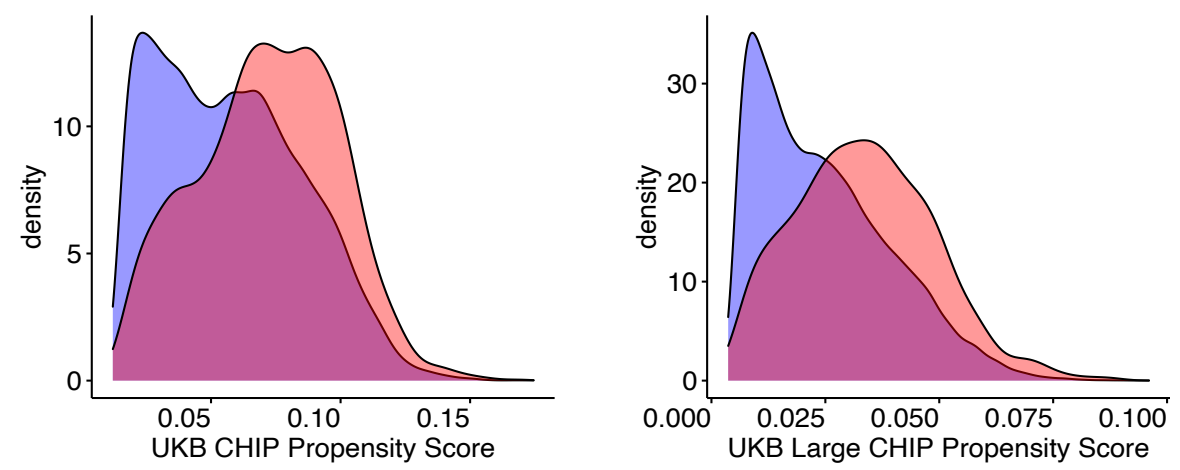

859

b.

\section{Association of CHIP}

863

864

865

866

867

868

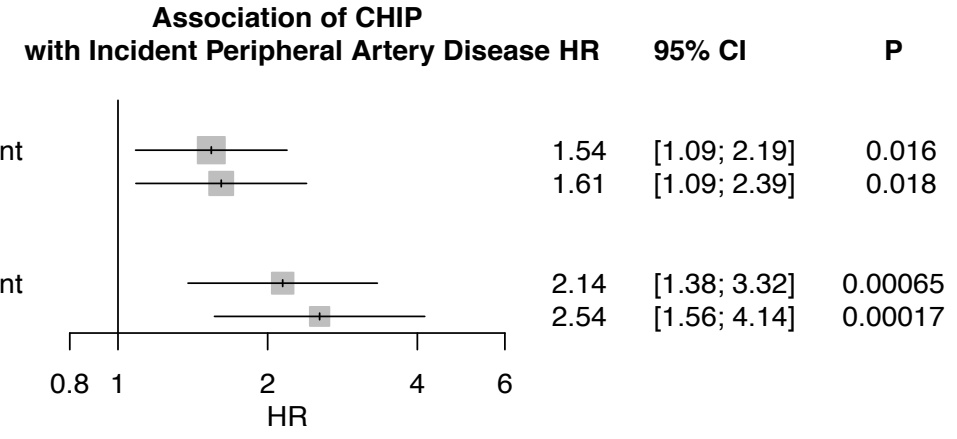

871

872 peripheral artery disease in the UK Biobank. a) Propensity scores by CHIP and Large CHIP

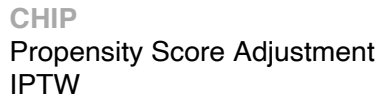
weighting (IPTW) for the CHIP and Large CHIP association with incident PAD in the UKB. $\mathrm{CHIP}=$ clonal hematopoiesis of indeterminate potential; $\mathrm{VAF}=$ variant allele fraction; $\mathrm{PAD}=$ peripheral artery disease 
medRxiv preprint doi: https://doi.org/10.1101/2021.08.22.21262430; this version posted August 23, 2021. The copyright holder for this preprint (which was not certified by peer review) is the author/funder, who has granted medRxiv a license to display the preprint in perpetuity.

It is made available under a CC-BY-NC-ND 4.0 International license .

881

882

883

884

Peripheral artery disease

UK Biobank

MGB Biobank

Overall

Coronary artery disease

UK Biobank

MGB Biobank

Overall

Any aortic aneurysm

UK Biobank

MGB Biobank

Overall

Association of Large CHIP

with Incident Disease

HR

$95 \% \mathrm{Cl}$

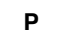

Cases (N)

Controls (N)

Cases with CHIP (N)

Controls with CHIP (N)

Abdominal aortic aneurysm

UK Biobank

Overall

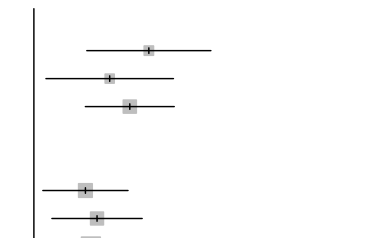

Other aneurysm

UK Biobank

MGB Biobank

Overall

2.25
1.71

[1.45; 3.49]

0.00028

$302 \quad 37,106$

$\begin{array}{ll}1.71 & {[1.09 ; 2.68]} \\ 1.97 & {[1.44 ; 2.69]}\end{array}$

0.02

373

11,875

22
21

879

$1.44 \quad[1.06 ; 1.94]$

$\begin{array}{lll}1.44 & {[1.06 ; 1.94]} & 0.018 \\ 1.56 & {[1.14 ; 2.15]} & 0.0061\end{array}$

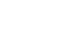

0.0061

1,044

35,564

11,178

45

833

$[1.20 ; 1.86] \quad 0.00031$

858

37,433
12,127

41

249

$2.24 \quad[1.29 ; 3.88] \quad 0.004$

$\begin{array}{llr}1.19 & {[0.37 ; 3.85]} & 0.77 \\ 2.00 & {[1.22 ; 3.29]} & 88.063\end{array}$

$\begin{array}{rr}194 & 37,433 \\ 78 & 12,127\end{array}$

14

895

$2.49 \quad[1.29 ; 4.80] \quad 0.0064$

113

37,528

10

900

$2.49 \quad[1.29 ; 4.80] \quad 0.0064$

$2.46 \quad[1.54 ; 3.95]$

0.00018

244

37,369

$\begin{array}{llccccc}1.29 & {[0.52 ; 3.18]} & 0.58 & 132 & 11,943 & 5 & 283 \\ 2.14 & {[1.41 ; 3.26]} & 0.00036 & & & \end{array}$

19
5

890

Chronic mesenteric ischemia

MGB Biobank

Overall

$[1.41 ; 3.26] \quad 0.00036$

12,424

3

310

Acute mesenteric ischemia

UK Biobank

Overall

Cerebral atherosclerosis

UK Biobank

MGB Biobank

Overall

Pan-arterial atherosclerosis

UK Biobank

MGB Biobank

Overall

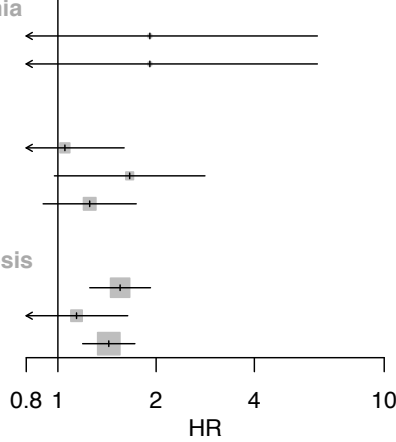

$\begin{array}{lll}14.70 & {[3.34 ; 64.70]} & 0.00038 \\ 14.70 & {[3.34 ; 64.70]} & 0.00038\end{array}$

886

$1.91 \quad[0.59 ; 6.24]$

0.28

49

37,598

3

908

$\begin{array}{lllllll}1.05 & {[0.69 ; 1.60]} & 0.82 & 623 & 36,850 & 23 & 886\end{array}$

$\begin{array}{lllllll}1.66 & {[0.98 ; 2.82]} & 0.062 & 269 & 11,990 & 15 & 288\end{array}$

889

$.25 \quad[0.90 ; 1.74] \quad 0.18$

$\begin{array}{llccc}1.55 & {[1.25 ; 1.92]} & 5.9 \mathrm{e}-05 & 1,875 & 34,366 \\ 1.14 & {[0.79 ; 1.64]} & 0.48 & 977 & 10,488\end{array}$

89
32

780

$1.43 \quad[1.19 ; 1.72]$

0.00013

888

890

891

892 Supplementary Figure VI: Association of Large CHIP (VAF $>10 \%$ ) with incident pan-arterial

893

894 atherosclerosis, combined across peripheral artery disease, coronary artery disease, aneurysms,

895 chronic and acute mesenteric ischemia, cerebral atherosclerosis, and renal artery stenosis. CHIP

896 
8 ! a.

$84 y$

900

901

902

903

904

905

906

907

908

909

910

911

912

913

914

915

916

917 TP53 or PPM1D

918 MGBBiobiank

919

920

921

922

923

924

925

926

927

928

929

930 b.

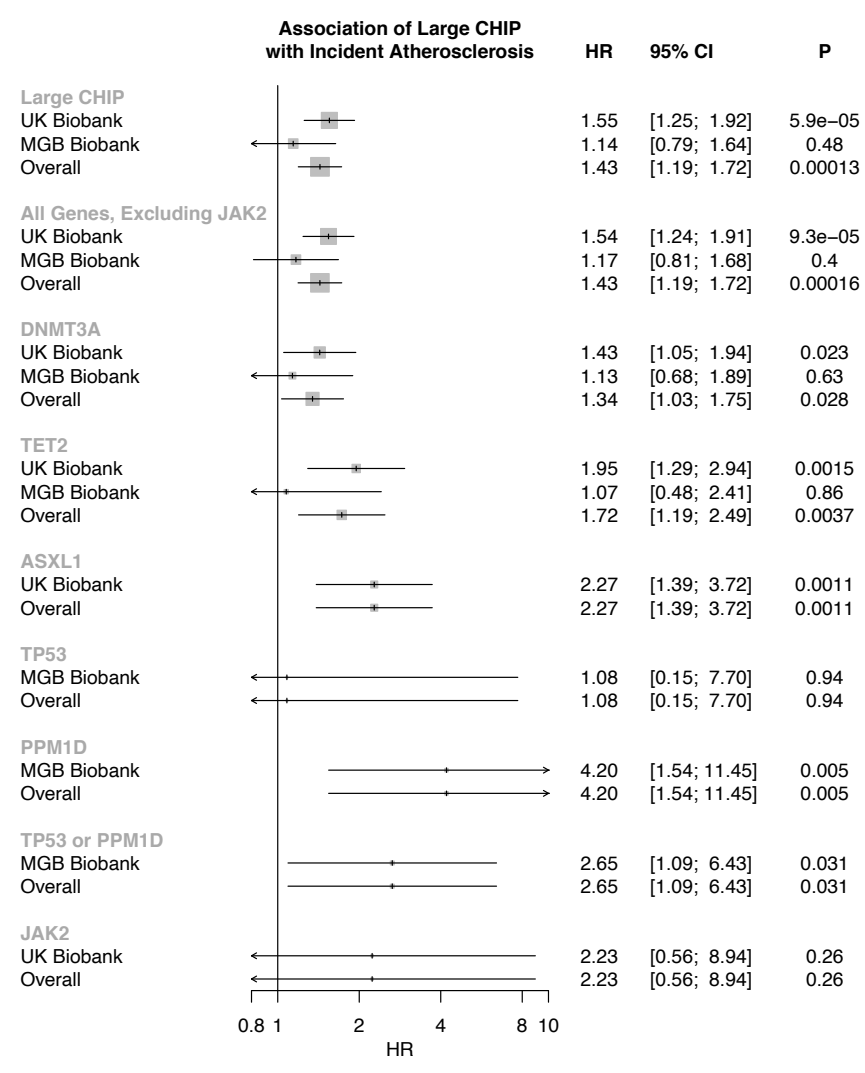

Supplementary Figure VII: Association of a) CHIP and b) Large CHIP genes with incident pan-arterial atherosclerosis, combined across peripheral artery disease, coronary artery disease, aneurysms, chronic and acute mesenteric ischemia, cerebral atherosclerosis, and renal artery stenosis. CHIP = clonal hematopoiesis of indeterminate potential; VAF $=$ variant allele fraction 
a.

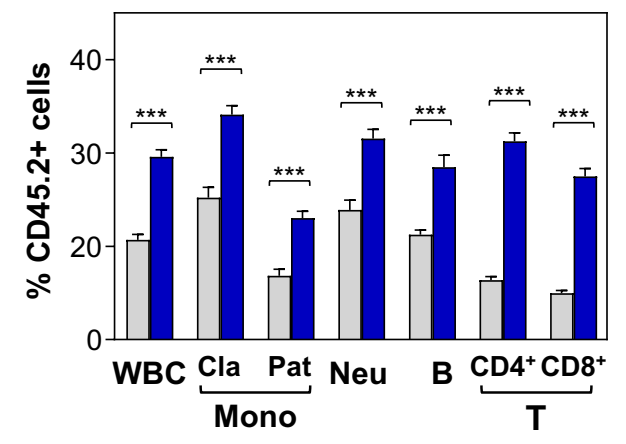

$20 \%$ WT BMT b.

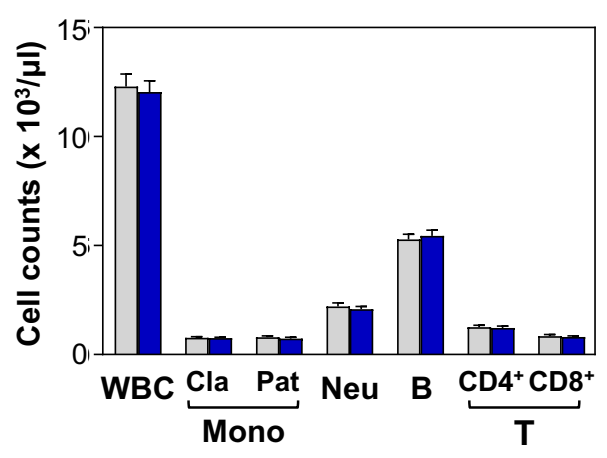

$20 \%$ KO BMT
933

934

935

936

937

938

939

940

941

942

943 d.

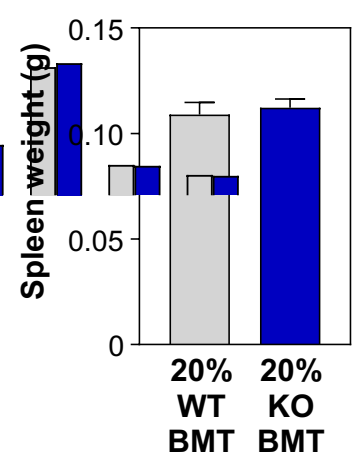

e.

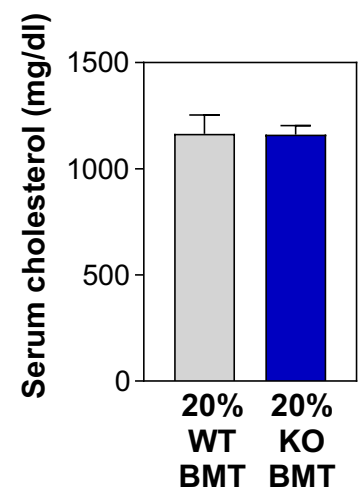

Supplementary Figure VIII: 20\% KO-BMT male mice and 20\% WT-BMT controls were fed a high-fat/high-cholesterol (HF/HC) diet for 9 weeks, starting 4 weeks after BMT. a) Percentage of CD45.2+ cells in different white blood cell (WBC) lineages in peripheral blood, evaluated by flow cytometry $(* * * p<0.001)$. b) Absolute counts of main WBC sub-populations in peripheral blood, evaluated by flow cytometry. c) Body weight. d) Spleen weight. e) Total cholesterol level in serum, evaluated by enzymatic methods.

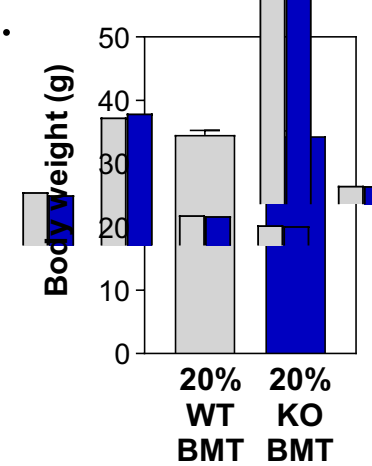


a.

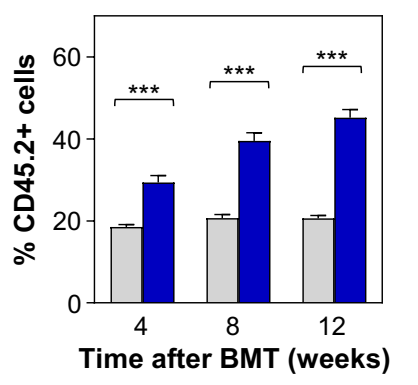

$\square 20 \%$ WT BMT b.

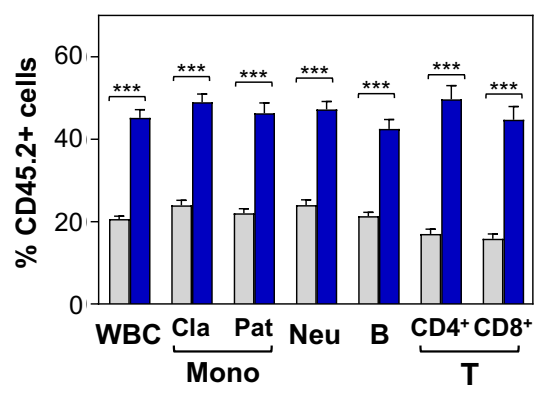

$20 \%$ KO BMT

c.
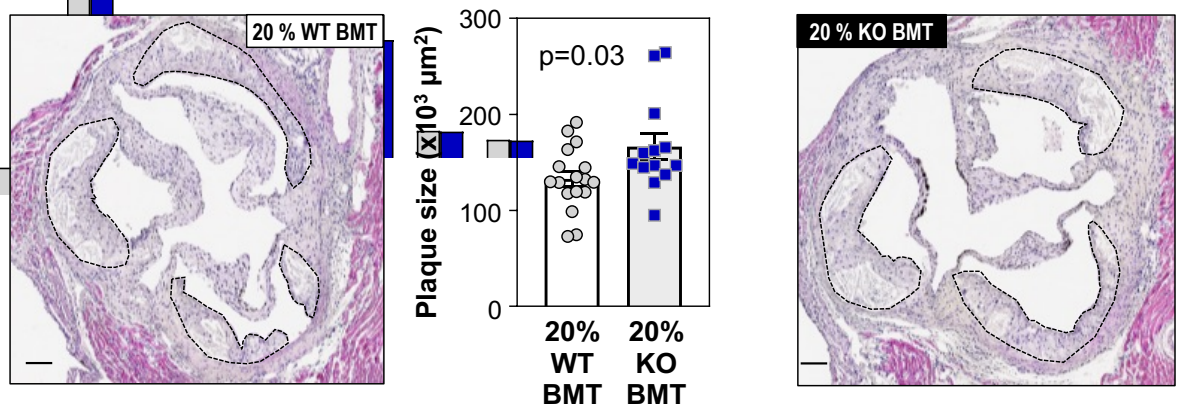

d.

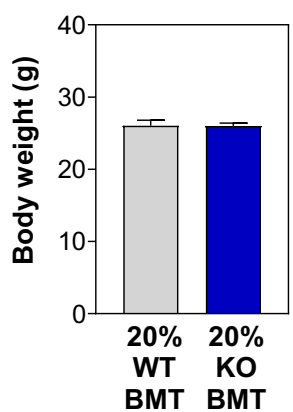

e.

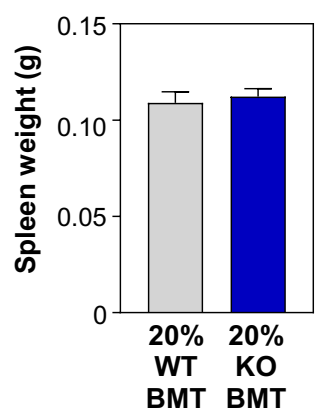

f.

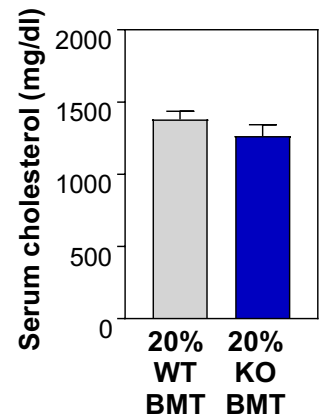

Supplementary Figure IX. 20\% KO-BMT female mice ( $\mathrm{n}=13$ ) and 20\% WT-BMT controls $(\mathrm{n}=17)$ were fed a high-fat/high-cholesterol $(\mathrm{HF} / \mathrm{HC})$ diet for 9 weeks, starting 4 weeks after BMT. a) Percentage of CD45.2+ in white blood cells at different timepoints, evaluated by flow cytometry $\left({ }^{* * *} \mathrm{p}<0.001\right)$. b) Percentage of CD45.2+ cells in different white blood cell (WBC) lineages in peripheral blood after 9 weeks on $\mathrm{HF} / \mathrm{HC}$ diet (13 weeks post-BMT), evaluated by flow cytometry $(* * * p<0.001)$. c) Aortic root plaque size. Representative images of hematoxylin and eosin-stained sections are shown; atherosclerotic plaques are delineated by dashed lines. Scale bars, $100 \mu \mathrm{m}$. d) Body weight. e) Spleen weight. f) Total cholesterol level in serum, evaluated by enzymatic methods. 
IL-1 $\beta$

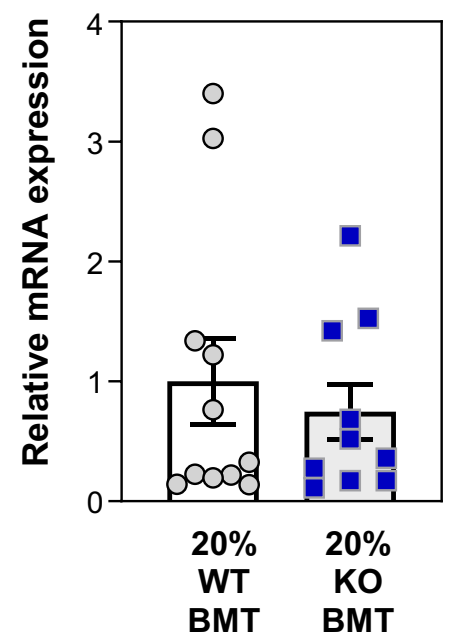

IL-6

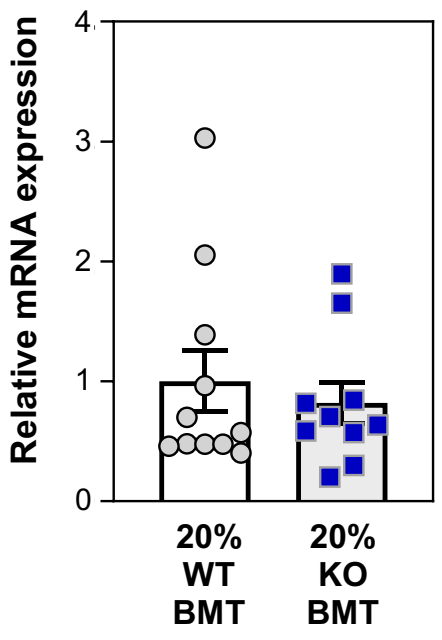

956

957

958

959

960

961

962

963

964

965

966

967

968

969

970

971

972

973

974

975

976

977

978

979

980

981

982

983

984

985

986
Supplementary Figure X. Aortic arch samples were obtained from HF/HC-fed 20\% WT-BMT mice $(n=11)$ or $20 \%$ KO-BMT mice $(n=10)$ and gene expression was analyzed by qPCR analysis. 
medRxiv preprint doi: https://doi.org/10.1101/2021.08.22.21262430; this version posted August 23, 2021. The copyright holder for this preprint (which was not certified by peer review) is the author/funder, who has granted medRxiv a license to display the preprint in perpetuity.

988 1. Conte MS, Bradbury AW, Kolh P, White JV, Dick F, Fitridge R, Mills JL, Ricco JB, 989 Suresh KR and Murad MH. Global vascular guidelines on the management of chronic limb990 threatening ischemia. J Vasc Surg. 2019;69:3S-125S.e40.

991 2. Jaiswal S, Fontanillas P, Flannick J, Manning A, Grauman PV, Mar BG, Lindsley RC, 992 Mermel CH, Burtt N, Chavez A, et al. Age-Related Clonal Hematopoiesis Associated with 993 Adverse Outcomes. New England Journal of Medicine. 2014;371:2488-2498.

994 3. Jaiswal S, Natarajan P, Silver AJ, Gibson CJ, Bick AG, Shvartz E, McConkey M, Gupta 995 N, Gabriel S, Ardissino D, et al. Clonal Hematopoiesis and Risk of Atherosclerotic 996 Cardiovascular Disease. New England Journal of Medicine. 2017;377:111-121.

997 4. Xie M, Lu C, Wang J, McLellan MD, Johnson KJ, Wendl MC, McMichael JF, Schmidt 998 HK, Yellapantula V, Miller CA, et al. Age-related mutations associated with clonal 999 hematopoietic expansion and malignancies. Nature medicine. 2014;20:1472-8.

1000 5. Genovese G, Kähler AK, Handsaker RE, Lindberg J, Rose SA, Bakhoum SF, Chambert 1001 K, Mick E, Neale BM, Fromer M, et al. Clonal hematopoiesis and blood-cancer risk inferred 1002 from blood DNA sequence. N Engl J Med. 2014;371:2477-87.

1003 6. Bick AG, Pirruccello JP, Griffin GK, Gupta N, Gabriel S, Saleheen D, Libby P, 1004 Kathiresan S and Natarajan P. Genetic Interleukin 6 Signaling Deficiency Attenuates

1005 Cardiovascular Risk in Clonal Hematopoiesis. Circulation. 2020;141:124-131.

1006 7. Bycroft C, Freeman C, Petkova D, Band G, Elliott LT, Sharp K, Motyer A, Vukcevic D, 1007 Delaneau O, O'Connell J, et al. The UK Biobank resource with deep phenotyping and genomic 1008 data. Nature. 2018;562:203-209.

1009 8. Smoller JW, Karlson EW, Green RC, Kathiresan S, MacArthur DG, Talkowski ME, 1010 Murphy SN and Weiss ST. An eMERGE Clinical Center at Partners Personalized Medicine. 1011 Journal of personalized medicine. 2016;6.

1012 9. Van Hout CV, Tachmazidou I, Backman JD, Hoffman JD, Liu D, Pandey AK, Gonzaga1013 Jauregui C, Khalid S, Ye B, Banerjee N, et al. Exome sequencing and characterization of 49,960

1014

1015

1016

1017

1018

1019

1020 individuals in the UK Biobank. Nature. 2020;586:749-756.

10. Bick AG, Weinstock JS, Nandakumar SK, Fulco CP, Bao EL, Zekavat SM, Szeto MD, Liao X, Leventhal MJ, Nasser J, et al. Inherited causes of clonal haematopoiesis in 97,691 whole genomes. Nature. 2020;586:763-768.

11. Jaiswal S, Fontanillas P, Flannick J, Manning A, Grauman PV, Mar BG, Lindsley RC, Mermel CH, Burtt N, Chavez A, et al. Age-related clonal hematopoiesis associated with adverse outcomes. N Engl J Med. 2014;371:2488-98.

1021 12. Jaiswal S, Natarajan P, Silver AJ, Gibson CJ, Bick AG, Shvartz E, McConkey M, Gupta

1022 N, Gabriel S, Ardissino D, et al. Clonal Hematopoiesis and Risk of Atherosclerotic

1023 Cardiovascular Disease. N Engl J Med. 2017;377:111-121.

1024 13. Klarin D, Lynch J, Aragam K, Chaffin M, Assimes TL, Huang J, Lee KM, Shao Q,

1025 Huffman JE, Natarajan P, et al. Genome-wide association study of peripheral artery disease in 1026 the Million Veteran Program. Nature medicine. 2019;25:1274-1279.

1027 14. Wu P, Gifford A, Meng X, Li X, Campbell H, Varley T, Zhao J, Carroll R, Bastarache L, 1028 Denny JC, et al. Mapping ICD-10 and ICD-10-CM Codes to Phecodes: Workflow Development 1029 and Initial Evaluation. JMIR Med Inform. 2019; 7:e14325. 
medRxiv preprint doi: https://doi.org/10.1101/2021.08.22.21262430; this version posted August 23, 2021. The copyright holder for this preprint (which was not certified by peer review) is the author/funder, who has granted medRxiv a license to display the preprint in perpetuity. It is made available under a CC-BY-NC-ND 4.0 International license .

15. Zekavat SM, Lin S-H, Bick AG, Liu A, Paruchuri K, Uddin MM, Ye Y, Yu Z, Liu X, Kamatani Y, et al. Hematopoietic mosaic chromosomal alterations and risk for infection among 767,891 individuals without blood cancer. medRxiv. 2020:2020.11.12.20230821.

16. Hernan MA, Brumback B and Robins JM. Marginal structural models to estimate the causal effect of zidovudine on the survival of HIV-positive men. Epidemiology. 2000;11:561-70. 17. Fuster JJ, MacLauchlan S, Zuriaga MA, Polackal MN, Ostriker AC, Chakraborty R, Wu CL, Sano S, Muralidharan S, Rius C, et al. Clonal hematopoiesis associated with TET2 deficiency accelerates atherosclerosis development in mice. Science (New York, NY). 2017;355:842-847.

18. Fuster JJ, Zuriaga MA, Zorita V, MacLauchlan S, Polackal MN, Viana-Huete V, FerrerPérez A, Matesanz N, Herrero-Cervera A, Sano S, et al. TET2-Loss-of-Function-Driven Clonal Hematopoiesis Exacerbates Experimental Insulin Resistance in Aging and Obesity. Cell reports. 2020;33:108326.

19. Denny JC, Bastarache L, Ritchie MD, Carroll RJ, Zink R, Mosley JD, Field JR, Pulley JM, Ramirez AH, Bowton E, et al. Systematic comparison of phenome-wide association study of electronic medical record data and genome-wide association study data. Nat Biotechnol. 2013;31:1102-10.

20. Visconte V, M ON and H JR. Mutations in Splicing Factor Genes in Myeloid Malignancies: Significance and Impact on Clinical Features. Cancers (Basel). 2019;11.

21. Bondar T and Medzhitov R. p53-mediated hematopoietic stem and progenitor cell competition. Cell Stem Cell. 2010;6:309-22.

22. Liu Y, Elf SE, Miyata Y, Sashida G, Liu Y, Huang G, Di Giandomenico S, Lee JM, Deblasio A, Menendez S, et al. p53 regulates hematopoietic stem cell quiescence. Cell Stem Cell. 2009;4:37-48.

23. TeKippe M, Harrison DE and Chen J. Expansion of hematopoietic stem cell phenotype and activity in Trp53-null mice. Exp Hematol. 2003;31:521-7.

24. Sano S, Oshima K, Wang Y, MacLauchlan S, Katanasaka Y, Sano M, Zuriaga MA, Yoshiyama M, Goukassian D, Cooper MA, et al. Tet2-Mediated Clonal Hematopoiesis Accelerates Heart Failure Through a Mechanism Involving the IL-1beta/NLRP3 Inflammasome. J Am Coll Cardiol. 2018;71:875-886.

25. Abplanalp WT, Cremer S, John D, Hoffmann J, Schuhmacher B, Merten M, Rieger MA, Vasa-Nicotera M, Zeiher AM and Dimmeler S. Clonal Hematopoiesis-Driver DNMT3A Mutations Alter Immune Cells in Heart Failure. Circ Res. 2021;128:216-228.

26. Sinha SK, Miikeda A, Fouladian Z, Mehrabian M, Edillor C, Shih D, Zhou Z, Paul MK, Charugundla S, Davis RC, et al. Local M-CSF (Macrophage Colony-Stimulating Factor) Expression Regulates Macrophage Proliferation and Apoptosis in Atherosclerosis. Arterioscler Thromb Vasc Biol. 2021;41:220-233.

27. Klarin D, Verma SS, Judy R, Dikilitas O, Wolford BN, Paranjpe I, Levin MG, Pan C, Tcheandjieu C, Spin JM, et al. Genetic Architecture of Abdominal Aortic Aneurysm in the Million Veteran Program. Circulation. 2020.

28. Shimizu K, Mitchell RN and Libby P. Inflammation and cellular immune responses in abdominal aortic aneurysms. Arterioscler Thromb Vasc Biol. 2006;26:987-94.

29. Boesten LS, Zadelaar AS, van Nieuwkoop A, Hu L, Teunisse AF, Jochemsen AG, Evers B, van de Water B, Gijbels MJ, van Vlijmen BJ, et al. Macrophage p53 controls macrophage death in atherosclerotic lesions of apolipoprotein E deficient mice. Atherosclerosis. 2009;207:399-404. 
medRxiv preprint doi: https://doi.org/10.1101/2021.08.22.21262430; this version posted August 23, 2021. The copyright holder for this preprint (which was not certified by peer review) is the author/funder, who has granted medRxiv a license to display the preprint in perpetuity.

It is made available under a CC-BY-NC-ND 4.0 International license .

1076 30. Fuster JJ, Fernandez P, Gonzalez-Navarro H, Silvestre C, Nabah YN and Andres V.

1077 Control of cell proliferation in atherosclerosis: insights from animal models and human studies.

1078 Cardiovasc Res. 2010;86:254-64.

1079 31. Guevara NV, Kim HS, Antonova EI and Chan L. The absence of p53 accelerates

1080 atherosclerosis by increasing cell proliferation in vivo. Nat Med. 1999;5:335-9.

1081 32. Mercer J, Figg N, Stoneman V, Braganza D and Bennett MR. Endogenous p53 protects

1082 vascular smooth muscle cells from apoptosis and reduces atherosclerosis in ApoE knockout

1083 mice. Circ Res. 2005;96:667-74.

1084 33. Merched AJ, Williams E and Chan L. Macrophage-specific p53 expression plays a

1085 crucial role in atherosclerosis development and plaque remodeling. Arterioscler Thromb Vasc

1086 Biol. 2003;23:1608-14.

1087 34. Sanz-Gonzalez SM, Barquin L, Garcia-Cao I, Roque M, Gonzalez JM, Fuster JJ, Castells

1088 MT, Flores JM, Serrano M and Andres V. Increased p53 gene dosage reduces neointimal

1089 thickening induced by mechanical injury but has no effect on native atherosclerosis. Cardiovasc

1090 Res. 2007;75:803-12.

1091 35. van Vlijmen BJ, Gerritsen G, Franken AL, Boesten LS, Kockx MM, Gijbels MJ,

1092 Vierboom MP, van Eck M, van De Water B, van Berkel TJ, et al. Macrophage p53 deficiency

1093 leads to enhanced atherosclerosis in APOE*3-Leiden transgenic mice. Circ Res. 2001;88:780-6.

1094 36. Robbins CS, Hilgendorf I, Weber GF, Theurl I, Iwamoto Y, Figueiredo JL, Gorbatov R,

1095 Sukhova GK, Gerhardt LM, Smyth D, et al. Local proliferation dominates lesional macrophage

1096 accumulation in atherosclerosis. Nat Med. 2013;19:1166-72.

1097 37. Heyde A, Rohde D, McAlpine CS, Zhang S, Hoyer FF, Gerold JM, Cheek D, Iwamoto

1098 Y, Schloss MJ, Vandoorne K, et al. Increased stem cell proliferation in atherosclerosis

1099 accelerates clonal hematopoiesis. Cell. 2021;184:1348-1361 e22.

1100 38. Fidler TP, Xue C, Yalcinkaya M, Hardaway B, Abramowicz S, Xiao T, Liu W, Thomas

1101 DG, Hajebrahimi MA, Pircher J, et al. The AIM2 inflammasome exacerbates atherosclerosis in

1102 clonal haematopoiesis. Nature. 2021;592:296-301.

1103 